\title{
SONORIDADES SUPERVIVIENTES
}

\author{
SURVIVING SONORITIES
}

\author{
Susan Campos-Fonseca* \\ DOI: https://doi.org/10.29043/liminar.vl8i2.760
}

Resumen: En el presente artículo se emplea un marco teórico que aplica el concepto umwelt propuesto por el biólogo Jacob von Uexküll, junto al de pathosformel del historiador Aby Warburg, de quien proviene también la idea de "imagen superviviente", a través de Georges Didi-Huberman. Esta idea se transforma aquí en "sonoridad superviviente" a partir de los estudios sonoros como posibilidad metodológica. La ciudad se convierte en umwelt ("mundo vivido"), habitada por pathosformel ("fórmulas de pathos"), las cuales se manifiestan en "sonoridades supervivientes" que pueden reconocerse como ethnoepistemes, en este caso, manifiestas en imaginarios estéticos y epistémicos occidentales, acerca de un "saber otro" del pueblo bribri-cabécar, comunidad indígena superviviente en Costa Rica.

Palabras clave: estudios sonoros, investigación artística, estudios decoloniales, arte centroamericano, estudios urbanos.

\begin{abstract}
This article uses a theoretical framework that applies the umwelt concept proposed by the biologist Jacob von uexküll, along with that of the historian Aby Warburg's pathosformel, from whom the idea of "surviving image" also comes, through Georges Didi-Huberman. This idea is transformed here into "surviving sonorities," from sound studies as a methodological possibility. The city becomes umwelt ("lived world"), inhabited by pathosformel ("pathos formulas"), which are manifested in "surviving sounds" that can be recognized as ethnoepistemes, in this case, manifest in Western aesthetic and epistemic imaginary about an "other-knowledge" of the Bribri-Cabécar people, a surviving indigenous community in Costa Rica.
\end{abstract}

Keywords: sound studies, artistic research, decolonial studies, Central American art, urban studies.

\footnotetext{
* Susan Campos Fonseca. Doctora en Música por la Universidad Autónoma de Madrid, España. Profesora-investigadora en la Universidad de Costa Rica, Costa Rica. Temas de especialización: estudios sonoros, epistemologías decolonialidades, transfeminismos e investigación artística, filosofía de la cultura y la tecnología. Correo electrónico: SUSAN.CAMPOS_F@ucr.ac.cr. ORCID: https://orcid.org/0000-00020645-0913
}

Enviado a dictamen: 11 de diciembre de 2019. Aprobación: 6 de abril de 2020.

Revisiones: 1. 


\section{Introducción: EGO City Guide San José}

E tema de este artículo está relacionado con una fecha, el 3 de agosto de 2018, día en el que asistí al concierto y a la feria de fanzines que se celebraron como cierre de la residencia artística que Pablo Martínez, jefe de programas del Museu d'Art Contemporani de Barcelona (MACBA), compartió con la artista argentina Felisa Pascual (Magui Dávila) y con la artista guatemalteca Marilyn Borror en la Casa Caníbal del Centro Cultural de España en San José, capital de Costa Rica.

Entre las actividades de esa noche destacan un evento con música noise, a cargo del artista sonoro costarricense Joan Villaperros, con su performance "Señora ruido", y el hip-hop lésbico de la artista argentina conocida como Macha Kiddo.

Las obras de Borror me causaron una fuerte impresión debido a su temática y conceptualización, además, coincidían con mi proyecto de investigación artística, vinculado en ese momento con la producción de mi álbum Indigenae (Campos, 2020), dedicado a obras para piano con técnicas extendidas compuestas por Marvin Camacho. El álbum incluye los "Haiku" I, II, IV y VII de sus Siete haikus (2012), los "Sorbones" I, IV y VI de sus Seis sorbones (2018), y Kö yöno: Canto para desgranar el maíz I y II (2018), obras a las que me referiré más adelante.

Esa noche me percaté de que varios de mis trabajos habían sido elaborados bajo inquietudes similares a las de Borror, aspecto que me gustaría analizar en otros espacios y que por ahora solo voy a referir: el proyecto B4343 "Materia prima: pueblo bribri y 'música de arte' en Costa Rica” (2014-2015); el proyecto B8140 "La ciudad creativa como vía para el desarrollo: una exploración de San José (Costa Rica) desde los estudios urbanos y las geo(bio)políticas audiovisuales" (20182019), ambos inscritos en el Instituto de Investigaciones en Arte-IIArte de la Universidad de Costa Rica; y el estudio titulado "Ruido y colonialidad interior", realizado en el marco del proyecto "Connected Worlds: The Caribbean, Origin of Modern World" (ConnecCaribbean-823846), desarrollado con apoyo del Programa Marie Skłodowska-Curie de la Unión Europea, proyecto dirigido por Consuelo Naranjo Orovio desde el Instituto de Historia del Consejo Superior de Investigaciones Científicas (CSIC) de Madrid, España, entre 2019 y 2022.

¿En qué consisten las obras de Marilyn Borror? y ¿cómo se relacionan con estas investigaciones? La primera pieza comprende un pequeño recipiente de cristal, que contiene dos pequeños trozos de papel, uno con un nombre impreso en color rojo, "Sibö", y otro que indica en letras negras: "Dios de los bribris". Sibö es la deidad creadora de la cosmología de este pueblo indígena. La segunda pieza es un fanzine titulado EGO City Guide San José, que reúne textos, imágenes, dibujos, fotografías, cartografías, poesía y collages tomados de publicaciones locales y traducidos del castellano al bribri (ver Fotos 1 y 2).

En el fanzine, Marilyn Borror firma junto a Julián Torres y Marga Siquiera el siguiente texto en castellano:

Este fanzine intenta ser una guía de la ciudad de San José, pero de una ciudad de la que no tenemos consciencia. Su objetivo es cuestionarnos a nosotrxs mismxs [sic] sobre el conocimiento que tenemos y el que creemos que debemos tener, sobre las jerarquías de los saberes, de los cuerpos, de las prácticas; sobre las múltiples colonizaciones que cargamos y las formas en que se manifiestan. Este imposible capitalismo Bribri [sic] nos da algunas pistas sobre qué caminos no tomar y qué otros es posible transformar (Borror, 2018:31).

El problema compartido que identificaba, como señalan Borror y sus colegas, estaba en las múltiples colonizaciones que cargamos y en las formas en que estas se manifiestan (Borror, 2018:31). La ciudad de San José (Costa Rica) se convertía en umwelt (mundo vivido), habitado por pathosformel (fórmulas de pathos), que se materializaban en "sonoridades supervivientes" que reconocía como ethnoepistemes. Borror y Camacho las evidenciaban en lo que entendían como un "saber otro" del pueblo bribri-cabécar. Coincidíamos en nuestro interés por la construcción estética y epistémica de la 
etnicidad, que nos permitía explorar colonizaciones y colonialidades del poder, el ser y el saber.

En relación con el marco teórico y metodológico, introduzco el concepto umwelt propuesto por el biólogo Jacob von Uexküll (1864-1944), el cual a su vez se interrelaciona con el de pathosformel del historiador Aby Warburg (1866-1929), de quien proviene la idea de "imagen superviviente", término que transformo en "sonoridad superviviente" a partir de los estudios sonoros como posibilidad metodológica. ${ }^{1}$ Dicho razonamiento me permite identificar el problema de estudio en términos etnoepistémicos, y cuestionar cómo en las obras de Borror y Camacho confluyen conceptos, ideas y experiencias acerca de lo "indígena superviviente" en tanto "saber otro" construido desde la occidentalidad hegemónica. La necesidad de recurrir a "lo indígena" en ambos casos expone fantasmagorías de "mundos vividos", que es lo que en este artículo se pretende explorar.

Para comenzar, el libro de Simone Borghi (2014) titulado La casa y el cosmos. El ritornelo y la música en el pensamiento de Deleuze y Guatari, donde el autor explora la relación entre umwelt y música, posibilitó establecer una conexión entre el marco teórico propuesto y el problema planteado. El texto de Borghi, leído dialógicamente con la obra La casa cósmica talamanqueña y sus simbolismos de González y González (1989), permitió pensar el umwelt que Borror y Camacho construían a partir de su consideración etnoepistémica del pueblo bribricabécar, comunidad indígena residente en la región de Talamanca, en el Caribe continental de Costa Rica.

Ambos textos proporcionaban también elementos para analizar la posibilidad de pensar los conceptos de umwelt y pathosformel en imágenes/sonoridades supervivientes. Por ejemplo, La casa cósmica de González y González (1989) informaba sobre la práctica del "sorbón" - presente en las composiciones de Camacho - ${ }^{2}$ y su relación con la "casa cósmica" - presente en el fanzine de Borror-. Ello identifica un pensar sonoro-corpográfico hacedor de esa "casa" que configura el mundo vivido en la tradición indígena. No obstante, me propuse entender el sorbón como un "hacer comunidad de cuerpo en vibración que late, oscilando", procurando no utilizar categorías como música (Borghi, 2014), que en este contexto expresarían una colonialidad epistémica del arte occidental hacia prácticas y saberes no-occidentales. Esto se suma a que umwelt no remite a mundos antropogénicos, sino a inter-especies -entre humanos y no-humanos-, aspecto importante a considerar en la cosmogonía indígena acuerpada por el sorbón y su relación con la casa cósmica; analizaré esto más adelante.

La necesidad de reflexionar sobre la colonialidad del concepto "música", manifiesto en las etnoepistemes identificadas en las obras que guían este estudio, se articula entonces con la propuesta de pensar sonoridades supervivientes. Me remito a la investigación de Mayra Estévez Trujillo (2016) dedicada a lo que ella identifica como "régimen colonial de la sonoridad". Otro recurso importante que utilizaré en esta exploración es la propuesta de Brabec de Mori, Lewi y García (2015), quienes proponen estudiar los "mundos audibles y cosmogonías sonoras" de pueblos no-occidentales evitando utilizar el término "música indígena" empleado tradicionalmente por la etnomusicología.

Respecto al problema etnoepistémico propuesto, considero importante mencionar dos antecedentes: “iArqueologías sonoras del presente?" (Campos, 2014) y "Prácticas sonoras de las poblaciones aborígenes de Costa Rica y su influencia en la música académica costarricense de los siglos XX y XXI: hacia una historiografía de imaginarios sonoros" (Gell, 2019). En estos artículos se analiza cómo las prácticas sonoras indígenas son fagocitadas, entendiéndolas como saberes "étnicos" encarnados que posibilitan el diseño de identidades sonoras nacionalistas, en este caso, asumidas como "costarricenses".

Consecuentemente, proponer un estudio de sonoridades supervivientes materializadas como etnoepistemes me remite a la siguiente pregunta de Aby Warburg: "icuáles son las formas corporales del tiempo superviviente?” (Didi-Huberman, 2014:173). Habitamos en tiempos de interfaces que hacen posible un pensamiento inter-especies (Sareen, 2017), las formas corporales resultado de estas supervivencias habitan "mundos vividos" territorializados, cuyos restos 
objetuales pueden ser documentados. Retornando a Borghi y su lectura de Uexküll, es posible ampliar "el concepto de sonoridad acústica al de significado de los objetos que entran como portadores de significado en el Umwelt de un sujeto" (Borghi, 2014:22). El mismo logra identificar un tejido sonoro capaz de "territorializar" en términos de Deleuze y Guatari.

Consecuentemente, el recorrido al que invita este artículo se establece a partir del umwelt de sujetos concretos, cuya obra territorializa, reterritorializa y desterritorializa mundos vividos entre la ciudad de San José, centro urbano, capital de Costa Rica, y una zona rural, el cantón de Turrialba, limítrofe entre el Valle Central y la zona atlántica del Caribe del país, donde se conservan restos arqueológicos de una "ciudad indígena" en ruinas actualmente conocida como Monumento Nacional Guayabo.

El fanzine de Borror y la música de Camacho remiten a imágenes/sonoridades supervivientes entre ambas ciudades. Refieren a formas corporales identificadas en lo indígena superviviente, lo urbano y el problema etnoepistémico planteado por "una ciudad de la que no tenemos consciencia"; de ahí la importancia de sumar a la investigación el trabajo del artista Jose Pablo Ureña. Su presencia en este artículo se justifica por mi álbum Indigende (Campos, 2020), que tiene como portada su obra "Extensión del panorama urbano. Supremacía del gris" (ver Ilustración 1), que muestra la silueta de la ciudad de San José y las montañas que la rodean como frecuencias sonoras. La obra de Ureña es una investigación artística desarrollada entre polos de proyectos académicos universitarios, motivada, como la de Marilyn Borror, por las pathosformel de ciudades centroamericanas.

\section{Ciudad de fantasmas}

En su estudio de la "imagen superviviente" DidiHuberman escribe sobre "un tiempo de fantasmas", cuyo referente directo es Aby Warburg, quien propone la pathosformel como "campo y vehículo de los movimientos supervivientes" (Didi-Huberman, 2014:172). Para este autor, "la Pathosformel, no deja de acompañar obstinadamente cada avance 'visible', es decir, legible y publicado, de la reflexión warburgiana sobre las imágenes [anunciando] su proyecto principal" (2014:173).

Esta gestualidad codificada me interesa porque evidencia la presencia de fantasmas, sus rastros en la ciudad, sus restos audibles, visibles, en fin, una condición fantasmal de "lo indígena" y de la "modernización" presentes en trabajos tan variados como son el fanzine Ego City Guide San José y los Seis sorbones.

Los sorbones de Camacho codifican sonoridades supervivientes en ese tránsito, por lo que propongo que la partitura puede ser leída como un sonograma. La acuarela de Ureña que elegí como portada de Indigenae me ayudó en este proceso de conceptualización, ya que puede ser entendida como un gráfico de frecuencias, lo que se evidencia en la silueta de la ciudad, que parece vibrar en conjunción con la montaña. Borror coincide en estas fantasmagorías cuando recurre a lo indígena superviviente para deconstruir lo urbano en su fanzine. Sin embargo, estas personas no han trabajado juntas, posiblemente ni siquiera han pensado en esto, pero mi investigación permite reconocer estos espectros y ponerlos en evidencia.

Identifico una coincidencia entre estas sonografías y lo que Didi-Huberman llama, remitiendo a Warburg, "sismografía de los tiempos movedizos" (2014:105). Las gráficas de partitura y acuarela pueden representar frecuencias supervivientes en la ciudad, sus "tiempos movedizos", su oscilación y desmoronamiento continuos. La obra de Ureña y los sorbones de Camacho coinciden también en su estética postminimalista, dejando al descubierto el gesto, la estructura viva de la sonoridad superviviente.

En el caso del compositor encuentro estructuras similares en su Meditación bribri (para contrabajo, 1984), Siete haikus (para piano, 2012), Memorias de Sibö (para quinteto de vientos, 2014), Seis sorbones (para piano, 2018) y Köyöno: Cantopara desgranar el maíz(para marimba y orquesta de cuerdas, 2018). ${ }^{3}$ La presencia del "ruido" y la oscilación que desborda el sistema diatónico tonal funcional motivan la utilización de notación gráfica y esquemas conceptuales. Esto evidencia la necesidad 
de representar algo no-representable por el sistema musical académico occidental: sonoridades noadoctrinadas que el "oído etnográfico" (Seeger, 2015) del compositor procura "traducir".

La obsesión de Marvin Camacho por los mundos audibles y las cosmogonías sonoras del pueblo bribricabécar está documentada en su obra. He procurado estudiar la razón, que en un primer momento me llevó a interpretarla como un "indigenismo". Sin embargo, cuando leí a Borror y sostuve en mi mano el pequeño recipiente de cristal que contenía no el "Aire de París" como en Marcel Duchamp (1919), si no a "Sibö", "Dios de los bribris", comprendí que podría plantear otra hipótesis: el compositor estaba escuchando algo y trataba de codificarlo con las herramientas que su entrenamiento como músico académico occidental le permitían. El intento aparecía una y otra vez en su obra, repitiéndose. Consolidándose como una característica de su lenguaje, estilo e incluso técnica.

Luego de realizar un análisis exhaustivo de su obra —desde 1980 hasta 2018-, identifiqué un viaje constante entre dos ciudades: San José y Turrialba. La pregunta entonces era, iqué escuchaba el compositor en ese tránsito? Desde 1986, Camacho trabaja en el Recinto Turrialba de la Sede del Atlántico de la Universidad de Costa Rica (UCR). Adquirió una propiedad cerca del Monumento Nacional Guayabo. La zona es un gran cementerio de restos de una civilización no identificada - presumiblemente huetares-, que habitó allí entre el 800 d.C. y el 1400 d.C., de la cual solo queda lo conservado como "monumento" y los artefactos resguardados en museos (Murillo, 2012:26). No obstante, actualmente la comunidad indígena superviviente, perteneciente al pueblo bribri-cabécar, tiene un poblado en Grano de Oro, cerca de Turrialba, una especie de "reserva indígena" en el distrito $12^{\circ}$ de Chirripó.

Esta es una zona de fantasmas. Desde la perspectiva de San José, lo indígena pretérito pertenece a los museos, donde sus restos desmembrados son estudiados y conservados. Un ejemplo de esta colonización epistémica propiciada por proyectos de investigación y exposiciones fue La metáfora de los sonidos. Materialización de la música en las poblaciones precolombinas (Molina y Aguilar, 2015), producida por los Museos del Banco Central de Costa Rica en 2015 y 2016. El proyecto contrató a dos músicos costarricenses para realizar la producción y composición, Andrés Cervilla y Joan Villaperros, quienes se encargaron de la interpretación y grabación de los artefactos conservados en los fondos del museo.

La metáfora de los sonidos (Molina y Aguilar, 2015) también abrió un concurso con el objetivo de invitar a compositores y compositoras nacionales e internacionales a utilizar el material sonoro resultado de las grabaciones realizadas a partir de una selección de artefactos conservados en el museo, cuyas posibilidades habían sido exploradas por los intérpretes contratados mediante su educación musical occidental. ${ }^{4}$ No se contó con la asesoría de miembros de las comunidades indígenas supervivientes residentes en el país, algo que hubiera propiciado un diálogo de saberes a partir de los artefactos.

Sin embargo, los artefactos sonoros conservados en museos deben ser estudiados tomando en cuenta la distancia que marca el oído etnográfico, que determina escuchas históricamente situadas. Proyectos como este no consideran un problema fundamental: que desconocemos cómo pensaban el sonido y el diseño tecnológico sonoro las comunidades que fabricaron y utilizaron estos artefactos. Diseccionarlas con nuestras epistemes no significa conocerlas, al contrario, las colonizamos usando nuestras epistemologías. Este proceso las convierte en otra cosa, pero no "en lo que fueron". Se evidencia así lo que Mayra Estévez (2016) identifica como el "régimen colonial de la sonoridad", materializado en supuestos como estos.

Proyectos como La metáfora de los sonidos coinciden con tendencias "indigenistas" y "primitivistas", movimientos estéticos occidentales cuyo propósito fue la usurpación del acervo simbólico de los pueblos indígenas, que fueron utilizados como "materia prima" para el diseño de identidades sonoras nacionalistas. Alejandro L. Madrid documenta y analiza este proceso en el caso de México, cuando escribe Los sonidos de la nación moderna - Premio de Musicología Casa de las 
Américas 2005- Lo indígena y la modernización de la nación no se dan la mano, al contrario, la relación entre "modernidad, modernización, modernismo y vanguardia en la periferia" (Madrid, 2005:13), como escribe el autor, es en realidad un proceso de negociación entre grupos de poder en los cuales las comunidades indígenas no tienen representación política.

Lo indígena es conveniente como fantasmagoría, como algo muerto y anónimo de lo que se puede disponer, tal y como señala Marilyn Borror en Ego City Guide San José. Borror y sus colegas imaginan "El San José que todos Queremos [sic]", y lo resumen en su editorial, describiéndolo como una ciudad que "vibra y se renueva", donde:

Los barrios que por años habían quedado en el olvido se han convertido en interesantes propuesta culinarias, comerciales y artísticas que enamoran los sentidos e invitan a los transeúntes a cruzar el umbral de los locales que los conforman. [...] Ego City Guide [sic] los [invita] a conocer las iniciativas que se suman al deseo colectivo por recuperar, mejorar y potenciar los espacios al este y oeste de San José, dándole una oportunidad de volver a brillar a decenas de casas de antaño (Borror, 2018:31).

El contenido del fanzine es realmente inquietante no solo porque realiza una radiografía precisa del discurso progresista y colonial de la gentrificación, sino porque lo escribe en castellano y bribri, imaginando un "imposible capitalismo Bribri [sic]". Una ciudad donde los fantasmas de las comunidades indígenas desplazadas, y los restos del esplendor de la ciudad modernista criolla decimonónica, vibran y se renuevan. San José, una ciudad de fantasmas.

\section{Hacer comunidad de cuerpo en vibración que late, oscilando}

Pensaré el sorbón como etnoepisteme. Me preguntaré: iqué puedo aprender si propongo que Marvin Camacho escucha una sonoridad superviviente que identifica con el sorbón? Ejercitaré la desobediencia epistémica de pensar el sorbón como umwelt (mundo-casa), no como música o danza según dicta el régimen colonial de la sonoridad. Esto me guía a otra ciudad, ahora en ruinas. Me dirijo entonces a ese lugar, viajo al Monumento Nacional Guayabo, espacio de "exploración arqueológica" desde finales del siglo XIX y zona protegida desde $1973 .{ }^{5}$

El trabajo de campo me ayuda a identificar un paisaje sonoro regido por los canales acuíferos, los restos de la ciudad parecen estar diseñados bajo este principio acústico. ${ }^{6}$ Los petroglifos localizados en la zona representan espirales y diferentes tipos zoomórficos relacionados con tierra y agua: lagarto y jaguar (Arias, Castrillo y Herrera, 2017). Entonces, en el sendero que rodea el sitio arqueológico encuentro una fotografía que muestra la vista aérea de la ciudad en ruinas en la que figura la leyenda: "Usted está aquí" (ver Foto 5).

Reconozco algo en esta imagen aérea, reviso las fotografías que realicé siguiendo la ruta de senderos y encuentro una conexión. Los tejidos en espirales y diseños zoomorfos de los petroglifos parecen coincidir con el diseño arquitectónico de la ciudad (ver Fotos 6 y 7) y quizás con el "campo y vehículo de los movimientos supervivientes" circulares y en espiral del sorbón. La ciudad parece vibrar en círculos y espirales. Identifico un hacer comunidad de cuerpo en vibración que late, oscilando como en el sorbón. ¿Será que estamos ante un pensamiento epistémico aural?, iante una arquitectura diseñada sobre principios biomiméticos?, ¿qué rol juegan en el diseño de este "mundo vivido" las fuentes acuíferas y los canales construidos por las personas que edificaron esta ciudad?

Ante estas preguntas, Grace Herrera y Ana Cecilia Arias, en su artículo "Los petrograbados de Guayabo de Turrialba, Costa Rica: un acercamiento a su significado", proponen que: "Al observar las imágenes de los petrograbados, estos nos dan la impresión de que pudieron representar: a) mapas geográficos. b) planos urbanísticos. c) redes de caminos. d) sistemas de irrigación [sic]" (Herrera y Arias, 2016:183).

Ahora bien, no se sabe con exactitud quiénes edificaron y habitaron la ciudad, pero sí qué comunidad 
indígena reside actualmente en los territorios de Turrialba. El primer problema que identifico es esta especie de "mezcla" entre tiempos y comunidades distintas. Existe un vacío, mi conexión con el sitio es el relato acerca de "lo indígena" en Costa Rica, y cómo este relato llega hasta la obra de un compositor que acudió a trabajar en la zona en los años ochenta del siglo pasado. La bibliografía relevante me informa que 1984 es:

elúltimo año de investigación arqueológica enmarcada y planificada dentro de un proyecto de investigación regional e intrasitio. Sería el año de las últimas investigaciones y resultados del proyecto Secuencia cultural y patrones de asentamiento en la región de Guayabo de Turrialba y con ello sería el final prematuro de todas las investigaciones relacionadas al proyecto.

En enero de 1984 se intensificó el trabajo de campo en tres zonas: el sitio Guayabo (UCR 43) y su periferia; el valle de Turrialba; y la región Talari en la cuenca del río Pacuare (Hurtado de Mendoza, 1984, en Murillo, 2012:87).

Estas fechas coinciden con la Meditación bribri para contrabajo (1984) de Marvin Camacho. Necesito documentar el contexto de gestación de la obra para vislumbrar los vínculos entre la etnografía sonora diseñada por Camacho y la etnografía acerca de "la música indígena costarricense", fraguada en consonancia con un momento histórico en que los proyectos de investigación arqueológica en el monumento Guayabo entraban en decadencia.

Las primeras evidencias se materializan en las publicaciones y producciones discográficas del compositor e investigador costarricense Jorge Luis Acevedo, quien, si bien no será el primero en interesarse por los artefactos y prácticas sonoras de las comunidades indígenas en Costa Rica, incorpora en su trabajo arte contemporáneo y transcripciones de grabaciones que realiza, tomadas de personas indígenas cuyos datos no siempre documenta.

Si bien le seguirán otros estudios, su trabajo será predominante hasta principios del siglo XXI, cuando otros dos costarricenses, la antropóloga Laura
Cervantes y el lingüista Adolfo Constenla, provean de nuevos enfoques teóricos y metodológicos. Cervantes en su trabajo dedicado al pueblo bribri, por ejemplo en su tesis doctoral Sounds like music: ritual speech events among the Bribri Indians of Costa Rica (2003), y Constenla en su libro Poesía bribri de lo cotidiano (2006), libro que marcará una nueva etapa del indigenismo en Costa Rica. Un periodo en que se cuestionará el "anonimato de las fuentes", abriendo el debate acerca de los derechos de autoría de las personas indígenas. Son dos ejemplos el Proyecto Jirondai (2018) y Nuevas voces / Antiguas palabras (s/f), promovidos por el periodista costarricense Luis Porras, desarrollado —el último de ellos- en colaboración con el Centro Cultural de España en Costa Rica.

Los trabajos de Acevedo, como Brevereseña de la música en Talamanca (1983), La música en las reservas indígenas de Costa Rica (1986) y el LP Ye Stsöke (Yo suelo cantar). Breve antología de la música indígena de Talamanca (1980? a y 1980?b), publicados con apoyo de la UCR, alimentarán la búsqueda de un "sonido propio" costarricense que canibaliza un legado entendido como "indígena" bajo el principio de "lo ancestral anónimo". Sus transcripciones y grabaciones de campo marcarán un paradigma y serán utilizadas como material para composiciones de diversos tipos, formas, géneros y soportes tecnológicos, desde sinfonías hasta cuartetos de cuerda, obras para piano, música de cámara, óperas, piezas etnotrónicas o rock progresivo, entre muchas otras modalidades (Campos, 2014; Gell, 2019).

En Costa Rica sobreviven ocho grupos indígenas: cabécares, bribris, ngäbe, térrabas, borucas, huetares, malekus y chorotegas, los cuales habitan veinticuatro territorios y hablan seis lenguas indígenas. El bribri es el idioma predominante en la actualidad. Las comunidades indígenas que habitan en Tucurrique, por ejemplo, lo conservan. Tucurrique marca una zona limítrofe entre los cantones de Jiménez y Turrialba, de la provincia de Cartago, en Costa Rica. Ambos cantones están en la ruta hacia el Atlántico, donde se localiza la provincia de Limón, que se teje con la cordillera de Talamanca. Intento con estos datos demarcar una posible "geobiopolítica" de sonoridades supervivientes 
que pueda evidenciar tiempos, espacios y lugares movedizos.?

Los vínculos entre la etnografía sonora diseñada por Camacho y la etnografía de la música indígena costarricense, documentada por Acevedo, tienen su propia genealogía y su huella genética queda identificada cuando localizo en el LP Ye Stsöke. Yo suelo cantar (Acevedo, 1980?a), una fuente similar a nivel fonético y melódico con los sorbones utilizados en el "Haiku VII" de los Siete haikus y en el "Sorbón I" de los Seis sorbones. No encontré fuentes similares en otros estudios, como los de Cervantes y Constenla.

La relación con el Monumento Nacional Guayabo requiere una consideración del vínculo entre ambos compositores. Jorge Luis Acevedo será quien introduzca a Marvin Camacho en el proceso de creación de Etapas Básicas de Música (EBM) en sedes y recintos de la UCR; ambos fundaron una EBM en el Recinto de Turrialba a mediados de los años ochenta, y Camacho trabajó en la zona durante más de treinta años, fijando su residencia cerca del sitio Guayabo.

Considero importante mencionar que existía una relación personal entre Acevedo y Camacho que marcó un antes y un después en su obra, lo que no quiere decir que ambos compositores compartieran una estética indigenista consensuada. La evidencia es la inclusión de sorbones grabados por Acevedo en Talamanca - aproximadamente en 1980-, en obras de Camacho compuestas en Turrialba en 2012 y 2018. Esta sinergia abre otro tipo de preguntas relacionadas con las etnoepistemes a las cuales recurre el compositor para diseñar umwelt (mundo-casa).

Él realiza una selección de esta "música de reserva indígena” y extrae el sorbón. ¿Por qué? Para contestar a esta pregunta procedo a documentar la relación entre el mito y el acto de edificar, construir una casa, del que brota la práctica del sorbón; es decir, propongo analizarlo como una práctica sonoro-arquitectónica.

\section{El sorbón: una práctica sonoro-arquitectónica}

En el apartado "Historia de la creación de la tierra" de su libro La casa cósmica, González y González informan que en la "versión bribri" del mito, "Sibú pensó que habría que bailar el sorbón en la fiesta y que tendría que invitar a bailar también a los diablos. Ya que él los había utilizado para que trabajaran en la construcción de su casa (el mundo)" (González y González, 1989:134-136).

En esta versión, durante la fiesta se reparte chocolate que, tanto en la exégesis bribri como en la cabécar, significa sangre: “[...] la historia muestra una transición desde la sangre cruda (tierra) a la sangre digerida (deyecciones en las que crecen plantas), a la sangre cocida (la bebida de chocolate que se comparte ceremonialmente)" (Bozzoli, 1979:18 citada en González y González, 1989:137). Esta sangre-chocolate se relaciona con un "accidente" - sacrificio planeado premeditadamente por Sibö- que sucede durante la práctica del sorbón, cuando una niña — versión bribrio un niño - versión cabécar- cae y es aplastada o aplastado por la comunidad.

El mito bribri cuenta que "todos los que bailan el sorbón empezaron a majarla [a la niña]"; su cuerpo desaparece aplastado "hasta convertirse en tierra". La madre - Surá en la versión cabécar - de la niña reclama a su hermano, Sibö, por haberla traicionado: "murió mi hija por la semilla de maíz y por lo que va a venir en este mundo". Este relato será retomado en Ego City Guide San José, donde se incluye un dibujo de la casa cósmica (Borror, 2018:13), y a continuación, el nombre de Sibö seguido de una oración a "La Madre Señora del Canto [...] la madre de toda nuestra semilla” (2018:2223). Borror parece remitir a estos mitos inter-especies donde humanos, diablos y otras especies animales y vegetales colaboran en la creación de la casa-mundo (ver Fotos 3 y 4 ).

En mi estudio de los Siete haikus de Marvin Camacho, incluido en "iArqueologías sonoras del presente?" (Campos, 2014), propongo que el compositor diseña un "hábitat" para ejercer su "instalar ser sonoro". En mi argumento recurro a la filósofa y teórica feminista Elizabeth Grosz, para quien: "La música es resultado de los movimientos de territorialización, desterritorialización y reterritorialización de fuerzas vibrantes en su articulación de (la división o diferencia entre) el cuerpo y la tierra" (Grosz, 2008, en Campos, 
2014:32). Consecuentemente, las versiones bribri y cabécar me llevan a pensar el sorbón como un "instalar ser sonoro", en coincidencia con esos movimientos y fuerzas vibrantes identificados por Grosz.

En “iArqueologías sonoras del presente?" consideraba los Siete haikus como "gestos decoloniales", pero al mismo tiempo me preguntaba:

[...] en qué medida puede una 'opción decolonial' pensar, ya no a los 'otros' de Occidente, de quienes le separa una 'herida colonial' — de la cual es parte - si no - como en el caso de Camacho [...] - a los Occidentes 'otros' que en estas 'herida' y 'opción', encuentran un camino de invención (Campos, 2014:42).

En este estudio elijo pensar que la clave está en la "gestualidad patética" estudiada por Warburg, en el gesto trágico del tiempo de fantasmas que habita la historia del arte, de la ciudad, del diseño sonoro de la experiencia viva: umwelt (Didi-Huberman, 2014). Camacho no recurre a la cultura griega, como en el caso de los estudios de Warburg. El compositor busca en los restos arqueológicos de culturas antiguas del territorio en que habita, eligiendo al pueblo bribri-cabécar.

Las ciencias recurren a las estadísticas, a las cifras; en este caso mis números están codificados en frecuencias dibujadas por Camacho, Ureña y Borror. Son gráficas de fantasmagorías captadas por la "subjetividad artística”. Soy consciente de que sigo el rastro de la colonialidad interior. En un trabajo reciente titulado "Noise, Sonic Experimentation, and Interior coloniality in Costa Rica" (Campos, 2018) analizo la tendencia generalizada entre artistas de diferentes géneros musicales - costarricenses y extranjeros residentes en el país- por recurrir a lo que entienden como una tradición musical "indígena costarricense", en estudios arqueológicos, antropológicos, etnomusicológicos y lingüísticos dedicados al pueblo bribri-cabécar.

En el estudio propongo que la utilización de estos recursos evidencia una colonialidad interior, manifestada en microcolonialismos que funcionan bajo premisas experimentales y decoloniales, utilizando el ruido y materiales etnográficos que se consideran representativos de una "otredad aural" (Campos, 2018:163).

En The Audible Past: Cultural Origins of Sound Reproduction, Jonathan Sterne (2003), pionero de los estudios sonoros (sound studies), identifica un "giro epistémico" en torno a la escucha facilitado por las tecnologías de grabación y reproducción sonora. En el caso de Warburg se encuentra un ejemplo de este "giro" cuando utiliza el término "sismografía", que Didi-Huberman identifica con los "tiempos movedizos" de la "imagen-pathos" (2014:105). Para ilustrarlo, cita a Burckhardt, quien se ve "obligado a hablar de una 'patología' y de una 'sintomatología' del tiempo" (DidiHuberman, 2014:107), y escribe:

el historiador de la cultura debe estar a la escucha de éstas como el sismógrafo de Schmidt está a la escucha de los movimientos de la corteza terrestre y el dinamógrafo de Charcot del cuerpo histérico sumido en un estado de 'superviviencia' sonámbula a la espera, en el aura hysterica de su crisis, de su propio seísmo (Didi-Huberman, 2014:112).

En mi caso encuentro este seísmo en las obras de Camachoy Borror, quienes a partir de diferentes técnicas, tecnologías y soportes actúan como sismógrafos y dinamógrafos de ciudades en colapso. Estas "personas creativas" materializan su escucha de ciudades en ruinas, como la indígena conservada en el Monumento Nacional Guayabo y la de San José, capital de Costa Rica que pretende ser creativa, inteligente, sustentable y un largo etcétera, en términos neoliberales; ciudades donde las crisis de un país confluyen, son confrontadas u omitidas.

Ego City Guide San José parodia los actuales fenómenos de gentrificación de la ciudad y las herramientas "creativas" con que se diseñan. El "inimaginable capitalismo bribri" y la "ciudad de la que no tenemos consciencia" se manifiestan en los síntomas de la colonialidad interior y sus símbolos, tratando de diseñar una identidad costarricense a partir del expolio del legado indígena, que se justifica 
con discursos de progreso y desarrollo no dirigidos a la población indígena, sino a las personas que puedan tener acceso a la "clase cultural" de la que habla Martha Rosner en su estudio sobre "arte y gentrificación" (Rosner, 2017).

Todavía continúo trabajando en un estudio exhaustivo de las evidencias que documentan este expolio de "lo indígena", con vistas a la construcción de un diseño de identidad nacional y de una "marca país". Pero considero importante señalarlo. A esto se suman otras culturas expoliadas como la "guanacasteca" - provincia de Guanacaste, al norte de Costa Rica, en la frontera con Nicaragua- y la afrocaribeña.

Ahora bien, una vez identificada la fuente del sorbón con que Marvin Camacho elabora sus obras Siete haikus y Seis sorbones, se observa que esta comprende un registro sonoro y la transcripción de un canto, cuyos fonemas conservan una ecología de saberes. El registro vocal y el paisaje sonoro conservados en la grabación de Acevedo (1980? y 1980?b) se tejen con significados cuya transcripción implica a su vez una traducción, tanto a los códigos de la gramática castellana como a los de la gramática musical occidental.

No debemos olvidar que se trata de un mundo audible no-occidental construido sonoramente para edificar una "casa cósmica". Este aspecto es fundamental, por eso no hablo de música sino de una práctica sonoro-arquitectónica. Necesito ejercitar la desobediencia epistémica de pensar "contra la música" —citando al etnomusicólogo Julio Mendívil (2016) porque la música no es universal, se volvió universal y totalitaria a partir de la imposición de un régimen colonial de la sonoridad, como señala Mayra Estévez (2016). Consecuentemente, elijo pensar en sonoridades supervivientes como ejercicio de desobediencia epistémica, pero icómo identificarlas?

\section{¿Sonogramas del Chthuluceno $?^{8}$}

En este artículo llego a la conclusión de que necesito pensar la notación gráfica de los Siete haikus y Seis sorbones con relación a los petroglifos de los sitios arqueológicos de Guayabo y Ta'lari (Herrera y Arias, 2016) y compararlos con los clústures recurrentes utilizados por el compositor, a mi criterio identificados como gráficos de frecuencias por la posibilidad de coincidir con los petroglifos; no obstante, esto requiere todavía de una investigación exhaustiva que continúa en proceso, de la cual esbozo aquí unos primeros resultados.

La visión aérea de la ciudad conservada en el sitio Guayabo me permitió observar coincidencias entre los diseños de los petroglifos zoomorfos y el diseño de la ciudad. Si se observa con atención, la zona de la calzada se divide en dos como la cola de un animal en movimiento representada en los petroglifos del lagarto y el jaguar que mencioné anteriormente, y así también los montículos de la ciudad se organizan de modo similar a los diseños de espirales esculpidos en las rocas. Este reconocimiento me llevó a pensar en la posibilidad de analizar un diseño biomimético en la ciudad, que podría materializarse también en las sonoridades supervivientes que pretendo identificar (ver Fotos 5, 6 y 7 ).

Pero antes de ahondar en esta posibilidad, necesito analizar algunos aspectos técnicos en los sorbones de Camacho. La fonética y la línea melódica utilizadas son el resultado de su propia transcripción. Revisadas las fuentes antropológicas, etnomusicológicas y lingüísticas autorizadas, no localicé ninguna afín; este es un dato importante. Ubicado el registro de audio realizado por Acevedo en los ochenta, en 2019 consulté con varios especialistas, incluido Luis Porras responsable del Proyecto Jirondai, quien me señaló que el autor del sorbón utilizado por Camacho era posiblemente Isabelito Morales. De ser así, la grabación había sido realizada en la comunidad de Sepecue, Talamanca. ${ }^{9}$

La transcripción, apropiación y adaptación a la codificación gramatical musical occidental del sorbón que se atribuye a Morales es de Camacho, así como la síntesis postminimalista en bloques y frases cortas, que conforma el diseño sonoro propuesto por el compositor, presente, en este caso, en la estructura del "Sorbón I". Según esta tesis, la notación gráfica de Camacho podría explorar etnoepistemes como sonoridades supervivientes (ver Ejemplos musicales 1 y 2 e Ilustraciones 2 y 3 ). 
Me interesa especialmente analizar las secuencias de clústeres de los manuscritos de Camacho en relación con el diseño de fluidos ondulantes de los petroglifos, relación que identifiqué gracias a la visión panorámica de San José propuesta por la acuarela de Ureña que elegí para Indigende. Tal conjunto de frecuencias me invita a pensar ciudades en vibración, resonantes. Jaques Attali señalaba que podíamos "aprender a juzgar una sociedad por sus ruidos, por su arte y por sus fiestas más que por sus estadísticas" (Attali, 1995:11).

Para estudiar los manuscritos de Camacho decidí trabajar con archivos de registros sonoros que conservaban sorbones indígenas. Este ejercicio me llevó a pensar los petroglifos como representación de mundos audibles y cosmogonías sonoras inter-especies, como el sorbón según el mito bribri-cabécar, que toma como "mentores" a especies de la flora y la fauna, inclusive a "los diablos", criaturas inter-especies en sí mismas.

Tales comparaciones me invitan a explorar unos estudios sonoros inter-especies biomiméticos, bioinspirados, biomateriales, como los propuestos por Jody Berland en Virtual Menageries. Animals as Mediators in Network Cultures (2019) y por Donna J. Haraway en Seguir con el problema. Generar parentesco en el Chthuluceno (2019), pero todavía es una especulación "SF" (Speculative Fabulation), como diría Haraway.

En el caso de los sorbones indígenas, no todas las fuentes identifican a quien los creó, lo que complica el seguimiento de las personas que los concibieron y de sus construcciones de sentido y significado. A esto se suma que ninguno de los sorbones cuyos textos fueron transcritos e incluidos en publicaciones científicas hasta la actualidad coincide con el texto utilizado por Camacho, obtenido del registro sonoro realizado por Acevedo posiblemente en 1980. Lo más cercano a una identificación posible del contenido del sorbón utilizado por Camacho me fue facilitado por Luis Porras, quien indicó:

En este sorbón Isabelito Morales hace una mezcla de varios sorbones: uno, taó kaé kä, el dueño de la serpiente, el espíritu del arco iris, una espiritualidad femenina, un espíritu convocado para trabajar en la creación de la tierra, y dos, shiton berke, un ave enorme, que llaman popularmente águila, tsalpú en su idioma, águila de montaña.

Probablemente don Isabelito en ese momento del sorbón, de ese canto colectivo, empieza a hacer una mezcla de esos dos temas, el sorbón de la dueña de las serpientes y el sorbón del aguila de montaña. ${ }^{10}$

Los sorbones documentados en escritos académicos no coincidían. La pregunta por el significado del texto y la corrección de su transcripción continúa sin respuesta. Si bien Luis Porras provee de grabaciones más actuales en su proyecto Nuevas voces / Antiguas palabras (2018-2020), estas tampoco coinciden. No obstante, el posible contenido que Porras identifica en los sorbones utilizados por Camacho, remite también a "espíritus inter-especies" convocados "para trabajar en la creación de la tierra", reiterando la cualidad sonoroarquitectónica del sorbón.

Frente al vacío en la traducción del texto decidí estudiar la vocalidad y el diseño sonoro conservados en las grabaciones disponibles. Encontré una guía en los estudios de la voz (voice studies) propuestos por Eidsheim y Meizal (2019), iniciando con una exploración etnoepistémica de la voz. En The Race of Sound, por ejemplo, Eidsheim (2019) analiza las formas en que los atributos sónicos aparentemente "naturales" -o naturalizados - en la voz y sus cualidades son producidos en realidad por prácticas sociales. Esta autora documenta cómo los oyentes miden la raza a través del sonido y localizan las subjetividades raciales en el timbre vocal: el color o el tono de una voz."

Con el propósito de analizar estas "subjetividades raciales en el timbre vocal" procedí a realizar una revisión crítica de fuentes audiovisuales que me permitieran conocer la vocalidad en la práctica del sorbón indígena. Luego de este proceso comparé los resultados con los sobornes incluidos en "Haiku VII" y "Sorbón I", sumando las interpretaciones del propio Camacho y de otros pianistas que han ejecutado las obras. Estas no coincidían.

La técnica vocal y su contenido etnoepistémico se manifestaban. La educación musical occidental 
hacía mella, podía identificarse claramente el régimen colonial de la sonoridad en la partitura de Camacho y en la ejecución de pianistas no-indígenas. Esto se materializaba en la afinación, el color, el timbre, el fraseo y la articulación, en síntesis: en la fonación y en la construcción epistémica del sonido escrito/traducido, tanto desde la gramática de la palabra como del sonido "musical". Entonces entendí que, si deseaba explorar mi tesis, debía ejercitar una desobediencia epistémicoperformativa.

Consecuentemente, realicé una investigación artística como intérprete vinculada al proceso, lo que dio como resultado varias grabaciones de las obras estudiadas, entre ellas, una primera versión del "Haiku VII" realizada el 5 de julio de 2016, a la que siguió una versión expandida en colaboración con los músicos mexicanos Julio Torres (guitarra eléctrica) y Pablo Chavarría (batería), llevada a cabo en la capilla del museo Na Bolom de San Cristóbal de Las Casas (Chiapas, México), el 9 de julio de 2016, incluida en el EP Zona de Silencio, de 2017, producido por el sello neoyorkino Irreverence Group Music. Luego realicé un trabajo colectivo para diseñar una deconstrucción de la Meditación bribri, grabada en vivo el l de noviembre de 2017, en colaboración con el contrabajista José Saavedra, incluyendo la electrónica en tiempo real de Ronald Bustamante y Karla Alfaro.

El aprendizaje resultado de estos procesos experimentales se encuentra reunido en el álbum Indigenae (Campos, 2020), que incluye mi desobediencia epistémica aplicada a los "Haikus" I, II, IV y VII, a los "Sorbones" I, IV y VI, y a Kö yöno: Canto para desgranar el maíz I y II; todos en versión para piano con técnicas extendidas, grabados en vivo en el auditorio de la Escuela de Artes Musicales de la UCR el ll de mayo de 2019.

El estudio de los petroglifos como sonogramas, y su análisis desde los estudios sonoros, está todavía en proceso. Me propongo realizar una digitalización de las imágenes recopiladas en varias fuentes, a las cuales se sumará un estudio del diseño físico-acústico de artefactos sonoros encontrados en sitios arqueológicos de Costa Rica conservados en museos. También realizaré una investigación de los materiales utilizados para construir los artefactos y de la composición de las rocas donde se localizan los petroglifos, considerando, por ejemplo, sus propiedades conductoras.

Los datos serán analizados utilizando programas de síntesis de sonido, aplicando metodologías de la biología y la ingeniería. Esto quizás provea enfoques para estudiar sonoridades supervivientes de pueblos nooccidentales, a partir de paradigmas - no-musicalesque consideren críticamente la interpretación colonial y colonizante que históricamente se impone a estos mundos audibles y a las cosmogonías sonoras. En el caso de Costa Rica, incluso revelándose contra:

El discurso de la supuesta blanquitud costarricense donde la población indígena era vista como ausente de nuestra historia y nuestros genes, aunado lógicamente al desinterés de construir una identidad a partir de un legado artefactual ligado a culturas "atrasadas", como sí lo habían hecho otros países americanos, contribuyó a la idea de un pasado indígena lejano y desaparecido, del cual solo nos quedan sus objetos artísticos (Corrales, 2000, en Murillo, 2012:7).

El estudio de sonoridades supervivientes continúa. Los retos de las ciudades siguen allí, desmoronándose. La pregunta acerca de cómo estudiar las sonoridades supervivientes conservadas y expuestas en dicho desmoronamiento brotó de la "intuición artística", así es como deseo "patentarlo". La investigación es guiada por etnoepistemes identificadas como indígenas en los trabajos de Camacho y Borror, pero también por los conceptos en lengua alemana que elegí para construir el marco teórico. La propuesta de Eidsheim evidencia cómo el sonido puede ser racializado por la escucha, las epistemes también.

Quisiera pensar las sonoridades supervivientes que busco como un fenómeno de ese Chthulucenoimaginado por Haraway (2019), como "hijas del compost". También como hijas del mundo ch'ixi, de esa "rara mezcla que somos", convocada por la socióloga boliviana Silvia Rivera Cusicanqui. Sonogramas del humus, del "vivir- 
con y morir-con" los desechos acumulados, tejidos por epistemes inter-especies aún por explorar.

\section{Conclusión: continuar}

La partitura como petroglifo; el petroglifo como sonograma; el sonograma como mapa de ciudades supervivientes. El canto, la voz, como recurso etnoespistémico que re/des/territorializa. Me propuse continuar por una vía experimental y especulativa, explorar las obras como intérprete y desaprender, ejercitando una vocalidad no-adoctrinada y una técnica no-pianística. El trabajo de campo se convirtió en un ejercicio de pensamiento situado en comunidades desarraigadas y empobrecidas, como Peralta, sitio ta'lari en el cantón de Jiménez (Cartago, Costa Rica), donde un petroglifo se conserva precariamente al lado de una pequeña casetilla de autobús, unas pocas casas sencillas y restos de un trapiche de azúcar.

Los cauces de los principales ríos de la zona, como el Reventazón, el Turrialba, el Colorado, el Pacuare y sus afluentes, actualmente oprimidos por las represas hidroeléctricas, marcan también el territorio. Un territorio fracturado en "tiempos movedizos", entre los canales acuíferos de una civilización perdida cuyos restos se desmoronan paulatinamente en el Monumento Nacional Guayabo, rodeado de las tecnologías hidráulicas emergentes del presente.

Soy consciente de que contemplo el paisaje como una exploradora académica occidental, guiada por los espectros de los petroglifos diseminados por el territorio de Turrialba, Tucurrique y Peralta, por ejemplo; restos de ciudades muertas ahora devoradas por la selva, desplazadas por las nuevas ciudades que se yuxtaponen unas a otras, como San José, en la Gran Área Metropolitana de Costa Rica.

Los bloques de sonoridades representadas por Camacho me enfrentan al ruido y a la colonialidad interior. El ruido representado en el clúster, como un racimo de sonidos saturados, pero también como un tejido de fantasmagorías. El ruido obliga a pensar desde la asimetría, desde la "caosmosis" (Guattari, 1996), y ese es para mí el reto de la desobediencia epistémica.
Borror y Camacho proponen una revisión de los discursos resultado de proyectos indigenistas, que en Costa Rica se consolidaron en los años ochenta del siglo pasado, en consonancia con la decadencia de las investigaciones arqueológicas en sitios como el Monumento Nacional Guayabo.

Concluyo que "somos-con" sonoridades supervivientes, brotadas de la herida colonial, latentes en la colonialidad interior que se teje con la obsolescencia tecnológica del registro sonoro desmembrado, descontextualizado, desmoronado, de mundos audibles que se extinguen, y de los cuales quizás solo nos queden los restos codificados/traducidos por el arte y la ciencia, ellos mismos, etnoepistémicos.

\section{Notas}

${ }^{1}$ Los estudios sonoros (sound studies) son un campo transdisciplinar centrado principalmente en la aparición del concepto de "sonido" en la modernidad occidental, con énfasis en el desarrollo de tecnologías de reproducción de sonido. El campo surgió a partir de artículos de la revista Social Studies of Science, publicados por académicos y académicas que trabajan en estudios de la ciencia, la tecnología y la comunicación. Sin embargo, se ha expandido enormemente y ahora participan en este campo una amplia gama de académicos que trabajan en música, antropología, arte sonoro, estudios para sordos, arquitectura y muchas áreas más. Se consideran textos fundacionales: The Audible Past de Jonathan Sterne (2003), The Soundscape: Our Sonic Environment and the Tuning of the World de R. Murray Schafer (1994) y Ruidos. Ensayo sobre la economía política de la música de Jacques Attali (1995). En su libro UIO-BOG Estudios Sonoros desde la Región Andina, Mayra Estévez (2008) propone que el "fin último [de esta área de estudios] es establecer una perspectiva epistemológica y política de las prácticas experimentales con sonido, en diálogo con proyectos provenientes de los Estudios Culturales, como son el proyecto modernidad/ colonialidad, las teorías poscoloniales y los estudios subalternos" (Estévez, 2008:18).

2 En este artículo se estudian los Seis sorbones del compositor Marvin Camacho, pero el antecedente de 
incluir el sorbón en su música se encuentra en el "Haiku VII" de los Siete haikus (Campos, 2014).

${ }^{3}$ En mi álbum Indigenae (Campos, 2020) incluyo una reducción y arreglo para piano con técnicas extendidas de la parte de orquesta. El marimbista invitado es Yónder Muñoz.

${ }^{4}$ En la plataforma el material estuvo dispuesto de forma abierta desde el 26 de abril al 17 de junio de 2015 en la dirección: https://lametaforadelossonidos.bandcamp. com/track/la-met-fora-de-los-sonidos, donde se informa: "Como parte de este proyecto, se comparten en esta plataforma, a manera de banco de sonidos gratuitos, el registro sonoro de una muestra de 24 instrumentos de la exhibición para uso creativo de compositores y músicos del mundo".

${ }^{5}$ Según informa Mauricio Murillo Herrera (2012:3) en su trabajo sobre "historia, investigaciones y manejo" del actual "monumento", los primeros datos acerca del sitio arqueológico Guayabo se encuentran en la correspondencia entre el hacendado José Ramón Rojas Troyo, dueño de la propiedad, y el naturalista alemán Helmuth Polakowsky, miembro de la Verein fur Erdkunde de Dresde y de la Sociedad Mexicana de Geografía y Estadística. También se identifican artefactos localizados en el sitio por Rojas Troyo, incluidos en el catálogo de la Exposición Nacional desarrollada en San José del 15 de septiembre al 15 de octubre de 1886. En la información general que puede localizarse en distintas fuentes se informa que el sitio arqueológico de Guayabo fue declarado monumento nacional por la Asamblea Legislativa mediante la Ley núm. 5300 el 13 de agosto de 1973, con una extensión de 65 hectáreas. En 1980, con el Decreto Ejecutivo núm. 11148-a, se amplió en 157.9 hectáreas, hasta alcanzar un total de 217.9 hectáreas. En el año 2014 se protegían un total de 233 hectáreas. El hecho de ser declarado como "monumento nacional" tiene como objetivo proteger su riqueza arqueológica y ofrecer oportunidades para actividades educativas, recreativas y científicas.

${ }^{6}$ El Monumento Nacional Guayabo fue declarado en 2009 Patrimonio Mundial de la Ingeniería por la Sociedad Americana de Ingeniería Civil (American Society of Civil Engineers, ASCE).
${ }^{7}$ Este fue el propósito de mi investigación "Ruido y colonialidad interior", desarrollada con apoyo del proyecto ConnecCaribbean-823846.

${ }^{8}$ Me remito aquí al término propuesto por Donna J. Haraway. cuando propone que: "Vivir-con y morir-con de manera recíproca y vigorosa en el Chthuluceno puede ser una respuesta feroz a los dictados del Ántropos y el Capital" (Haraway, 2019:21). Se refiere al término Chthuluceno frente a los de Antropoceno y Capitaloceno.

${ }^{9}$ Entrevista con Luis Porras realizada el 1 de octubre de 2019.

${ }^{10}$ Entrevista con Luis Porras realizada el 1 de octubre de 2019.

${ }^{11}$ En el resumen original: "In The Race of Sound Nina Sun Eidsheim traces the ways in which sonic attributes that might seem natural, such as the voice and its qualities, are socially produced. Eidsheim illustrates how listeners measure race through sound and locate racial subjectivities in vocal timbre the color or tone of a voice" (Eidsheim, 2019, traducción propia).

\section{Referencias}

Acevedo, Jorge Luis (1980?a) YeStsöke. Yo suelo cantar [LP]. San José: Universidad de Costa Rica.

Acevedo, Jorge Luis (1980?b) Breve antología de la música indígena de Talamanca. San José, Costa Rica: Universidad de Costa Rica.

Acevedo, Jorge Luis (1983). Brevereseñadela músicaen Talamanca. San José, Costa Rica: Universidad de Costa Rica.

Acevedo, Jorge Luis (1986). La música en las reservas indígenas de Costa Rica. San José, Costa Rica: Universidad de Costa Rica.

Arias, Ana Cecilia, Floria Castrillo y Grace Herrera (2017). Una historia escrita en piedra. Petrograbados de Guayabo de Turrialba. San José, Costa Rica: Universidad de Costa Rica.

Attali, Jaques (1995). Ruidos. Ensayo sobre la economía política de la música. Ciudad de México: Siglo XXI.

Berland, Jody (2019). Virtual Menageries. Animals as Mediators in Network Cultures. Boston: The MIT Press.

Borghi, Simone (2014). La casa y el cosmos: el ritornelo y la música enel pensamiento de Deleuze y Guattari. Buenos Aires: Cactus. 
Borror, Marilyn (2018). EGO City Guide San José [fanzine]. San José: Casa Caníbal del Centro Cultural de España.

Brabec de Mori, B., Matthias Lewy y Miguel A. García (eds.) (2015). Sudaméricaysusmundosaudibles: cosmologías y prácticas sonoras de los pueblos índigenas. Berlín: IberoAmerikanisches Institut Preußischer Kulturbesitz/ Gebr. Mann Verlag. Disponible en: https://www. iai.spkberlin.de/fileadmin/dokumentenbibliothek/ Estudios_Indiana/Estudios_Indiana_8_online.pdf

Camacho Villegas, Marvin (2012). Siete haikus [partitura]. Turrialba, Costa Rica. Disponible en: https:// marvincamacho.com/catalogo/

Camacho Villegas, Marvin (2018). Kö yöno:canto para desgranar el maíz. Seis sorbones [partituras inéditas]. Turrialba, Costa Rica.

Campos Fonseca, Susan (2014). "¿Arqueologías sonoras del presente?" En Casa de las Américas. Boletín Música, 37, 27-43.

Campos Fonseca, Susan (2016). Haiku VII [grabación]. Nueva York: Irreverence Group Music. Disponible en: https:/ soundcloud.com/susan-campos-fonseca/haiku-vii

Campos Fonseca, Susan (2018). "Noise, Sonic Experimentation, and Interior coloniality in Costa Rica”. En Ana R. Alonso-Minutti, Eduardo Herrera y Alejandro L. Madrid (eds.), Experimentalisms in practice. Music perspectives from Latin America. Nueva York: Oxford University Press, pp. 161-185.

Campos Fonseca, Susan (2019). Sorbon VI [grabación]. Nueva York: Irreverence Group Music. Disponible en: https://soundcloud.com/susan-campos-fonseca/ sorbon-vi

Campos Fonseca, Susan (2020). Indigenae [disco compacto]. Nueva York: Irreverence Group Music. Disponible en: https://www.irreverencegroupmusic. com/recordings/indigenae

Cervantes Gamboa, Laura (2003). Sounds like music: ritual speech events among the Bribri Indians of Costa Rica. Tesis de doctorado en Antropología, The University of Texas at Austin, Estados Unidos de América.

Comaroff, Jean y John L. Comaroff (2011). Etnicidad S.A., Buenos Aires y Madrid: Katz Editores.

Constenla Umaña, Adolfo (2006). Poesía bribri de lo cotidiano: treinta y siete cantos de afecto, devoción, trabajo y entretenimiento. San José, Costa Rica: Universidad de Costa Rica.

Didi-Huberman, Georges (2014). La imagen superviviente. Historia del arte y tiempo de los fantasmas según Aby Warburg. Madrid: ABADA Editores.

Eidsheim, Nina (2019). The Race of Sound. Listening, Timbre, and Vocality in African American Music. Durham \& Londres: Duke University Press.

Eidsheim, Nina y Katherine Meizel (2019). The Oxford Handbook of Voice Studies. Nueva York: Oxford University Press.

Estévez Trujillo, Mayra Patricia (2008). UIO-BOG Estudios Sonoros desde la Región Andina. Quito: Trama Editorial.

Estévez Trujillo, Mayra Patricia (2016). Estudios sonoros en y desde Latinoamérica: del régimen colonial de la sonoridad a las sonoridades de la sanación. Tesis de doctorado en Estudios Culturales Latinoamericanos, Universidad Andina Simón Bolívar, Sede Ecuador, Quito.

Gell Fernández-Cueto, Leonardo (2019). "Prácticas sonoras de las poblaciones aborígenes de Costa Rica y su influencia en la música académica costarricense de los siglos XX y XXI: hacia una historiografía de imaginarios sonoros (1986-2016)". En Escena. Revista de las Artes, 79(1), 177-207.

González, Alfredo y Fernando González (1989). La casa cósmica talamanqueña y sus simbolismos. San José, Costa Rica: EUNED.

Guattari, Félix (1996). Caosmosis. Buenos Aires: Manantial.

Haraway, Donna J. (2019). Seguir con el problema. Generar parentesco en Chthuluceno. Bilbao: Consonni.

Herrera, Grace y Ana Cecilia Arias (2016). "Los petrograbados de Guayabo de Turrialba, Costa Rica: un acercamiento a su significado". En Revista Herencia, 29(2), 175-204

Madrid, Alejandro L. (2005). Los sonidos de la nación moderna. La Habana: Casa de las Américas.

Mendívil, Julio (2016). En contra de la música. Buenos Aires: Gourmet Musical Ediciones.

Molina, Priscilla y Mónica Aguilar Molina (2015). La metáfora de los sonidos. Materialización de la música en las poblaciones precolombinas. San José: Fundación Museos Banco Central de Costa Rica. 
Murillo Herrera, Mauricio (2012). Monumento Arqueológico Nacional Guayabo de Turrialba. San José: EUNED.

Museo del Banco Central de Costa Rica (2015). La metáfora de los sonidos [grabación]. Disponible en: https:// lametaforadelossonidos.bandcamp.com/track/la-metfora-de-los-sonidos.

Nuevas voces / Antiguas palabras (2018/2020) [grabación]. S/l: Cooperación Española Cultura San José/ Proyecto Jirondai. Disponible en: https:// nuevasvocesantiguaspalabras.bandcamp.com/

Proyecto Jirondai (2018). Lugares de la memoria. Compilatorio [grabación]. S/1: bandcamp. Disponible en https:// jirondai.bandcamp.com/

Rosner, Martha (2017). Arte y gentrificación, Buenos Aires: Caja Negra.

Sareen, Harpreet (2017). Cyborg Botany: Augmented Plants as Sensors, Displays and Actuators. Tesis para obtener el grado de Master of Science in Media Arts and Sciences en el Massachusetts Institute of Technology, Massachussetts. Disponible en: https:/dspace. mit.edu/handle/1721.1/114063 (consultado el 9 de septiembre de 2019).

Schafer, R. Murray (1994). The Soundscape: Our Sonic Environment and the Tuning of the World. Rochester, Vermont: Destiny Books.

Seeger, A. (2015). "El oído etnográfico". En Brabec de Mori, B., Matthias Lewy y Miguel A. García (eds.), Sudamérica y sus mundos audibles: cosmologías y prácticas sonoras de los pueblos indígenas. Berlín: IberoAmerikanisches Institut Preußischer Kulturbesitz/ Gebr. Mann Verlag, pp. 27-36.

Sterne, Jonathan (2003). The Audible Past: Cultural Origins of Sound Reproduction, Durham y Londres: Duke University Press.

\section{Ejemplo musical 1. Fragmento del "Sorbón I" de Marvin Camacho, cc. 1-7}
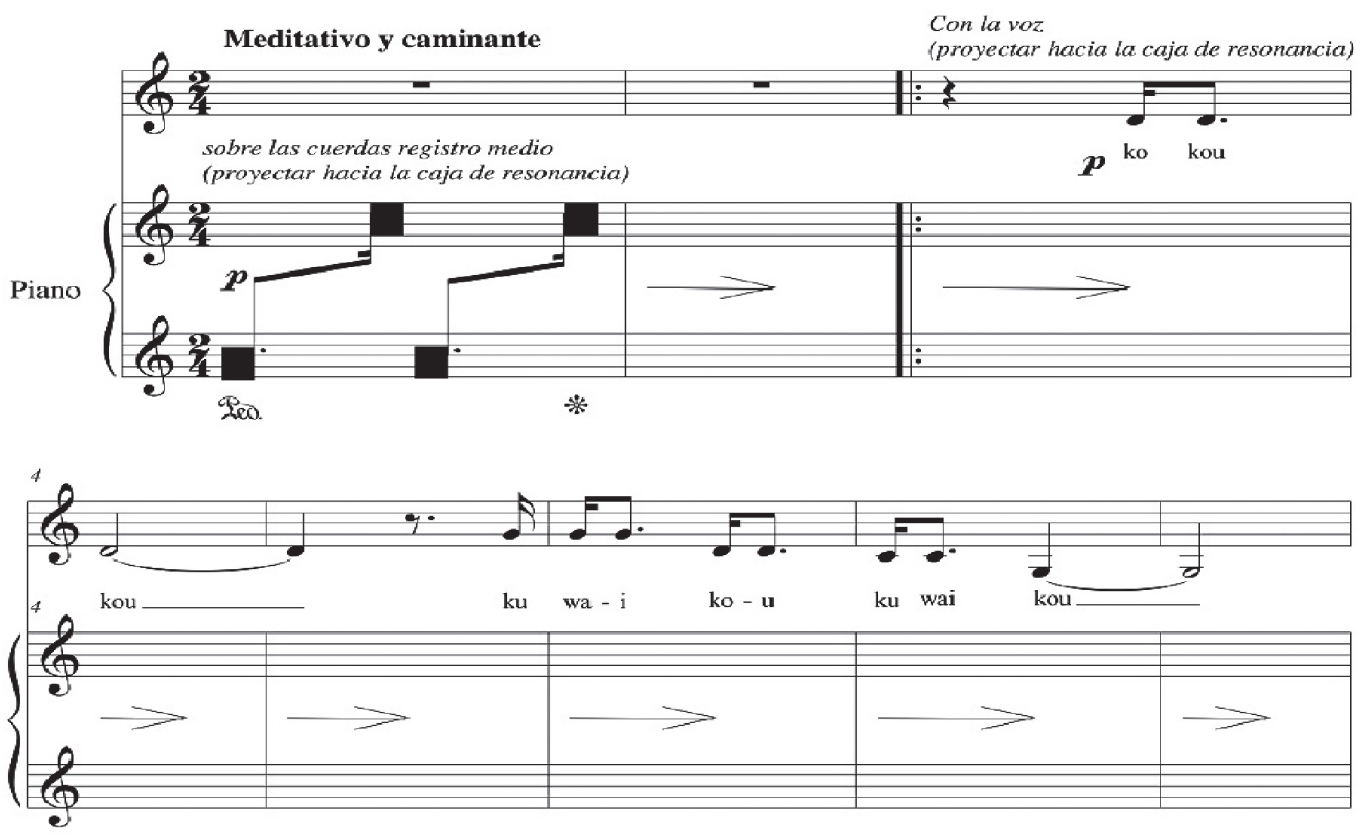

Fuente: edición de Diego Castillo. 
Ejemplo musical 2. Fragmento del “Sorbón I" de Marvin Camacho, cc. 23-24

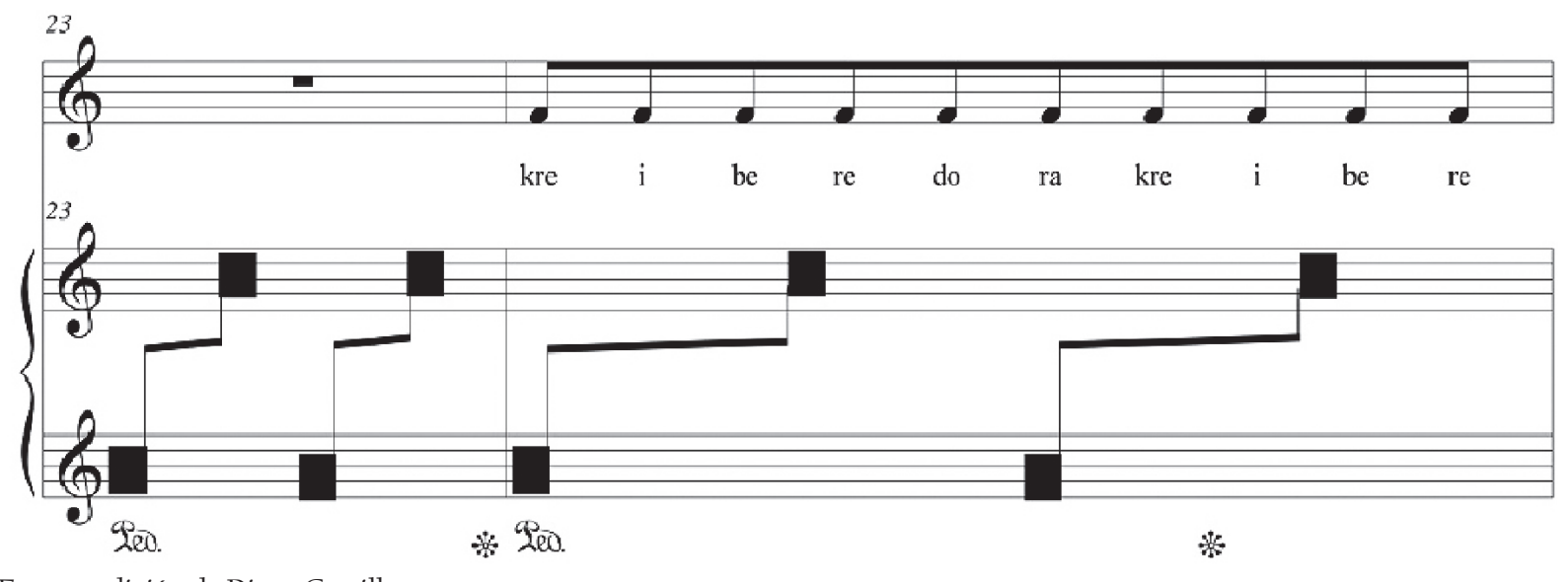

Fuente: edición de Diego Castillo.

Foto 1. Borror, M. (2018). Fanzine EGO City Guide San José y pieza conceptual Sibö

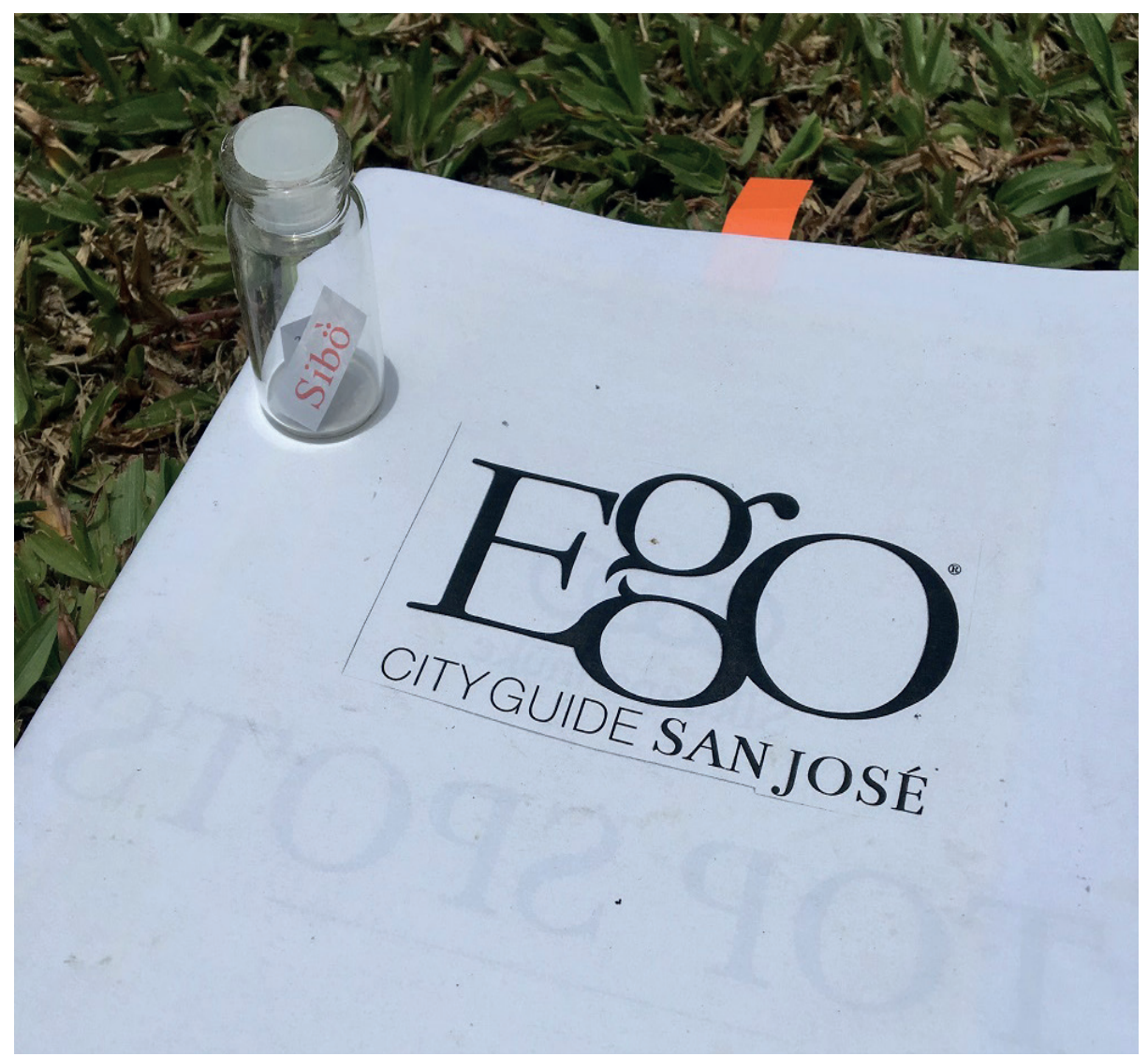

Fuente: fotografía de Susan Campos (2019). 
Foto 2. Borror, M. (2018). Fanzine EGO City Guide San José y pieza conceptual Sibö

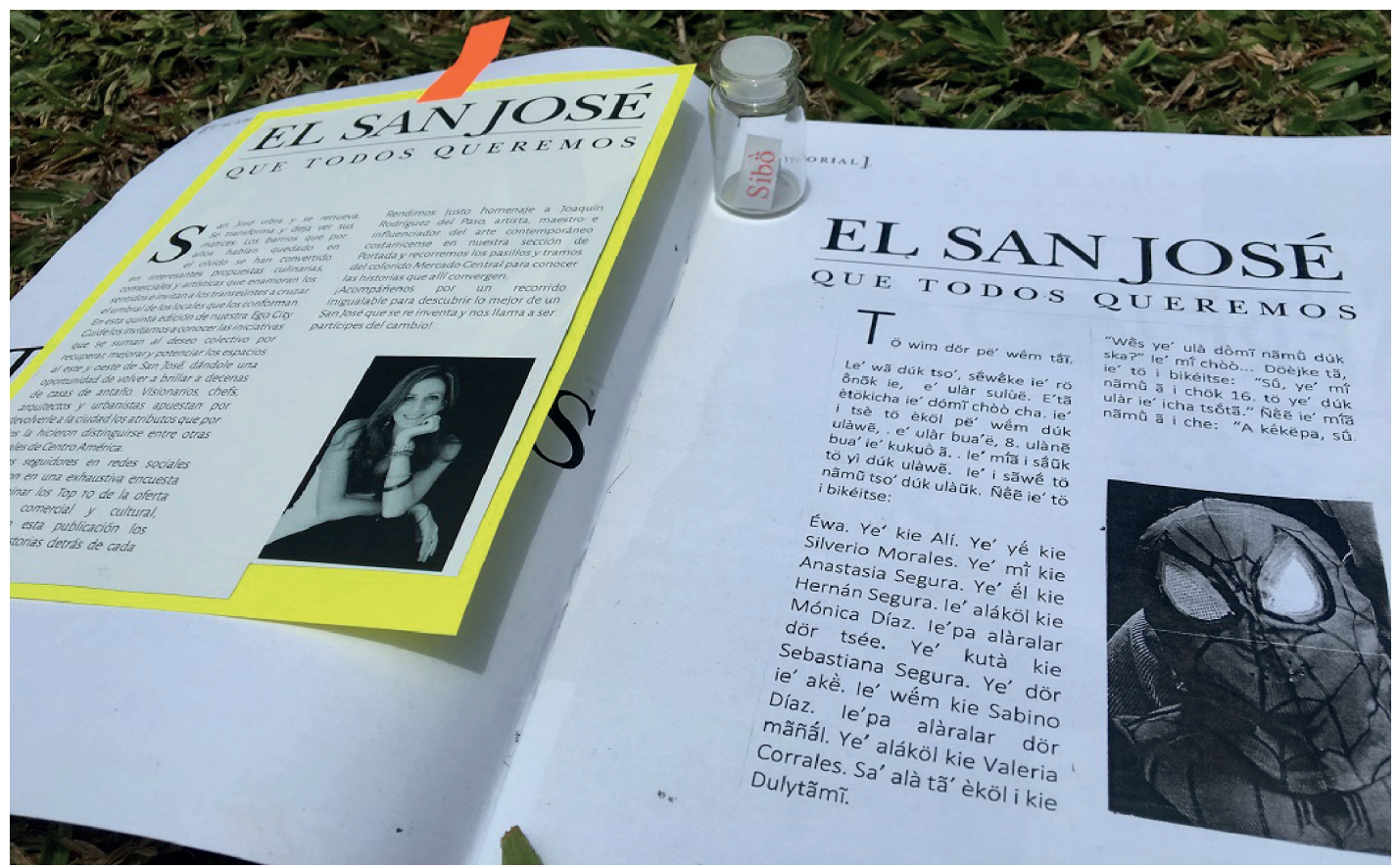

Fuente: fotografía de Susan Campos (2019).

Foto 3. Oración a “La Madre Señora del Canto" en Ego City Guide San José

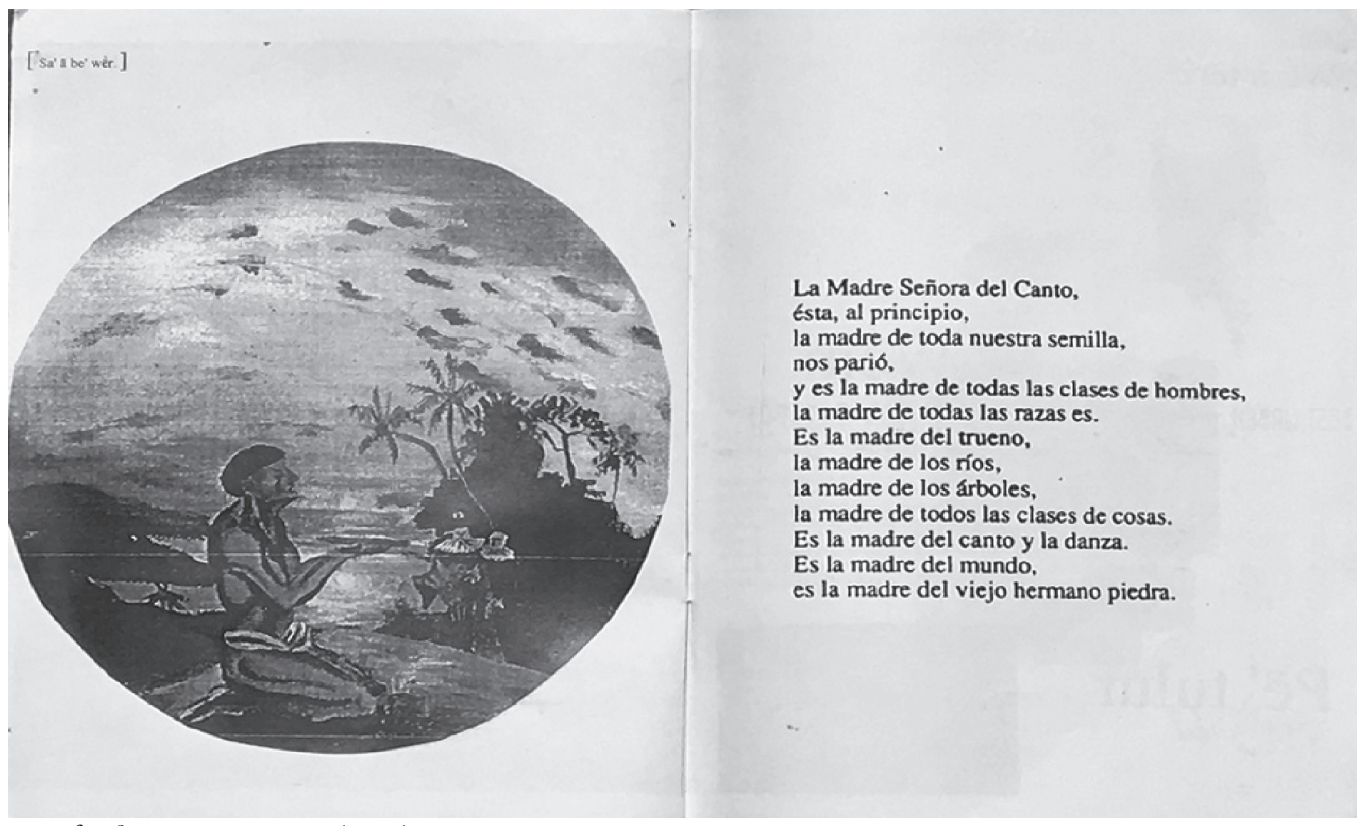

Fuente: fotografía de Susan Campos (2019). 
Foto 4. La “casa cósmica” en Ego City Guide San José (2018)
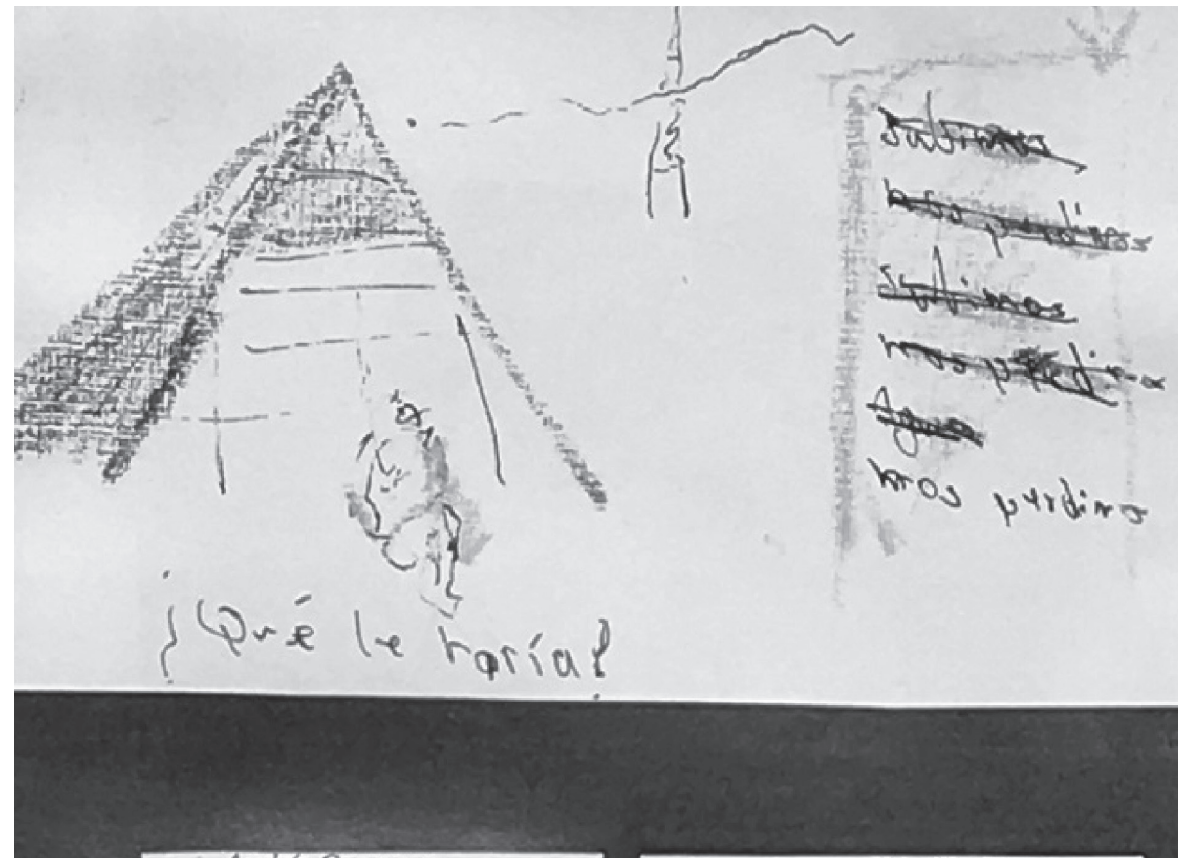

Andrés Carranza ARTISTA Y ARQUITECTO

"Wềs ye' ulà dômĩ nămừ dúk ska?" le' mí chòò... Döèjke tã, ie' tö i bikéitse: "Sú, ye' mî́ nãmừ ã i chök 16. tồ ye' dúk ulàr ié icha tsớtã." Nè̃ẽ ié mía nãmữ ã i che: "A kếkèpa, sú, ye' dúk i' ulàr be' icha tsốtã." . Nãmû̀ tö i che: "Be' i che." le' tö i che:. "Tố, ye' dúk ulàr be' icha tsốtã; be' kĩi kiànẽ, sứ s mî i mốũk ètökicha?

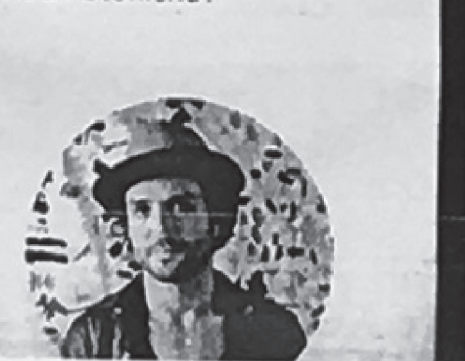

Priscilla Monge ARTISTA

Éwa. Ye' kie Ali. Ye' yế kie Silverio Morales. Ye' mi kie Anastasia Segura. Ye' ếl kie Hernán Segura. le' aláköl kie Mónica Diaz. le'pa alàralar dör tsée. Ye' kutà kie Sebastiana Segura. Ye' dör ie' akề. le' wếm kie Sabino Díaz. Iépa alàralar dör mãñ̂ấl. Ye' alákōl kie Valeria Corrales. Sa' alà tă' èköl i kie Dulytãmĩ.

Fuente: fotografía de Susan Campos (2019). 
Foto 5. Vista aérea del sitio arqueológico, mapa localizado en el Monumento Nacional Guayabo

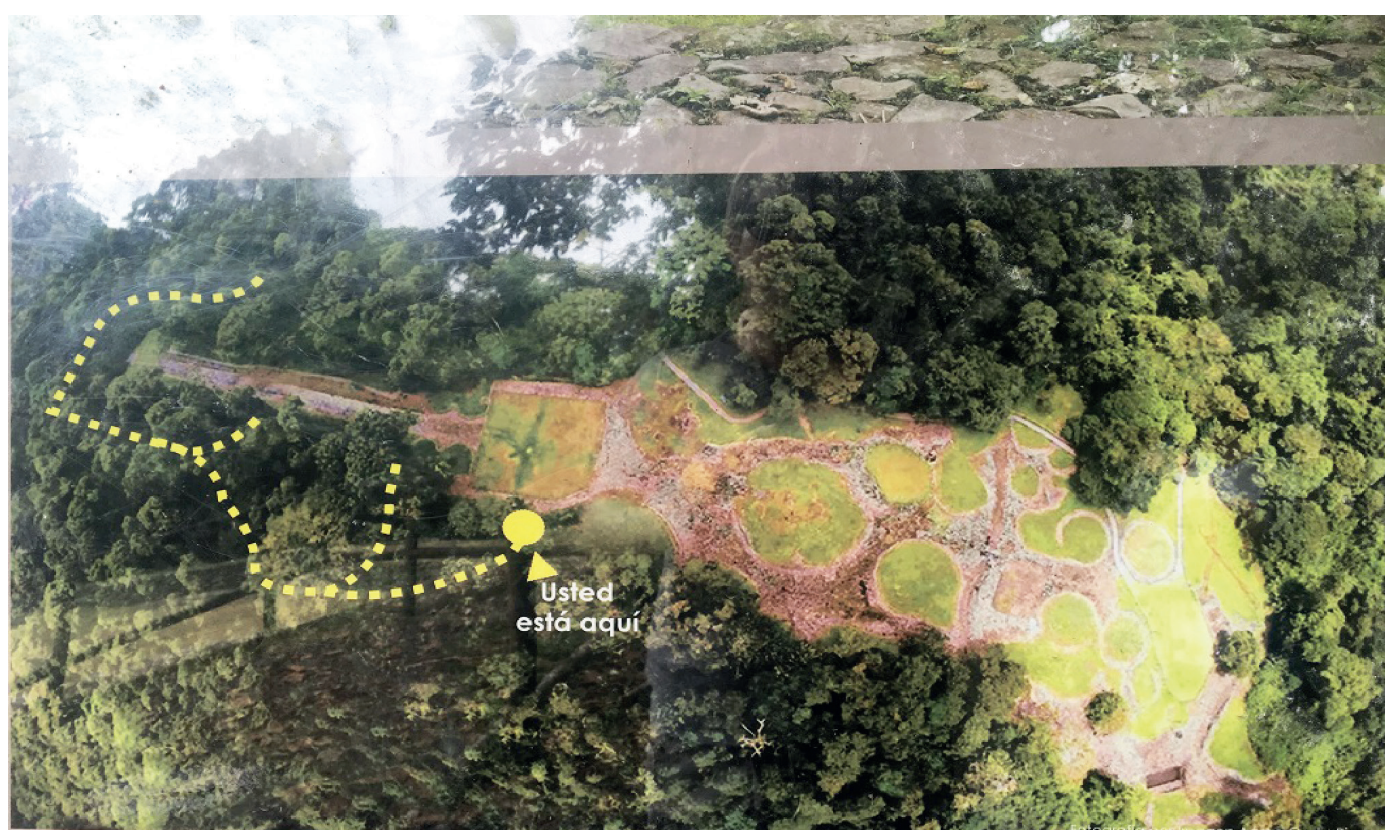

Fuente: fotografía de Susan Campos (2019).

Foto 6. Petroglifo zoomorfo localizado en el Monumento Guayabo

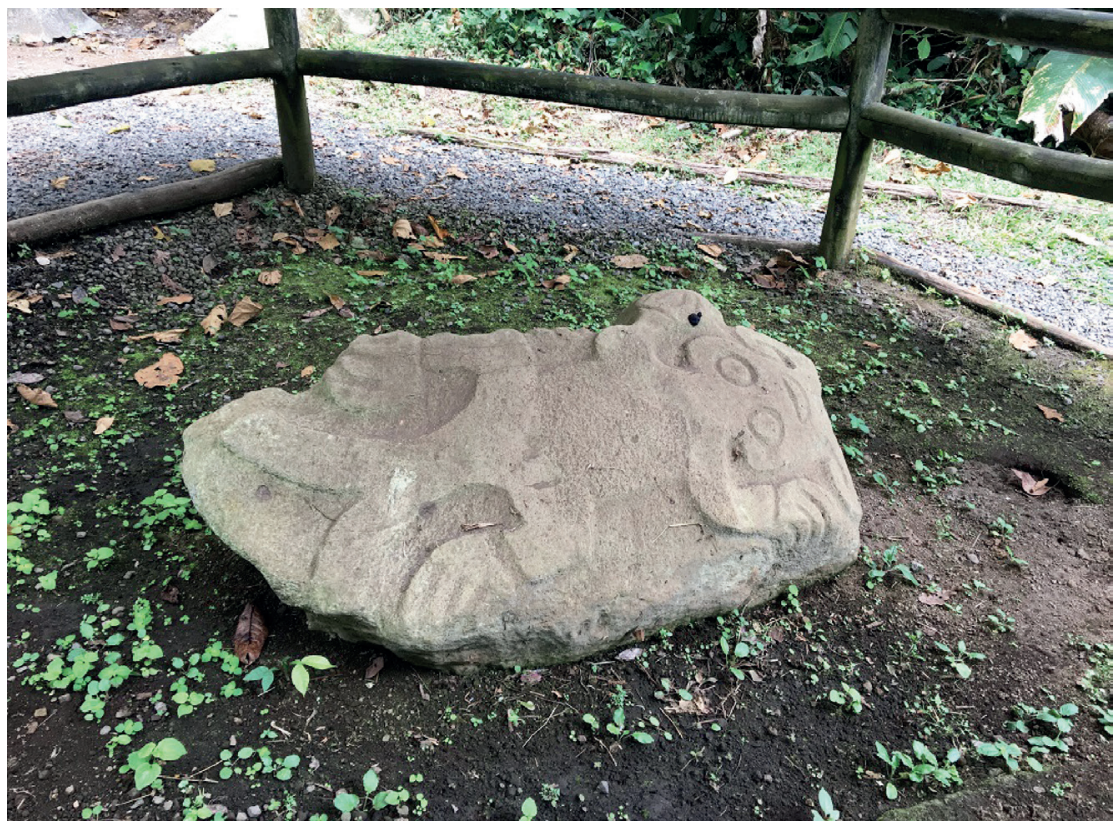

Fuente: fotografía de Susan Campos (2019). 
Foto 7. Petroglifo localizado a la entrada del Monumento Nacional Guayabo

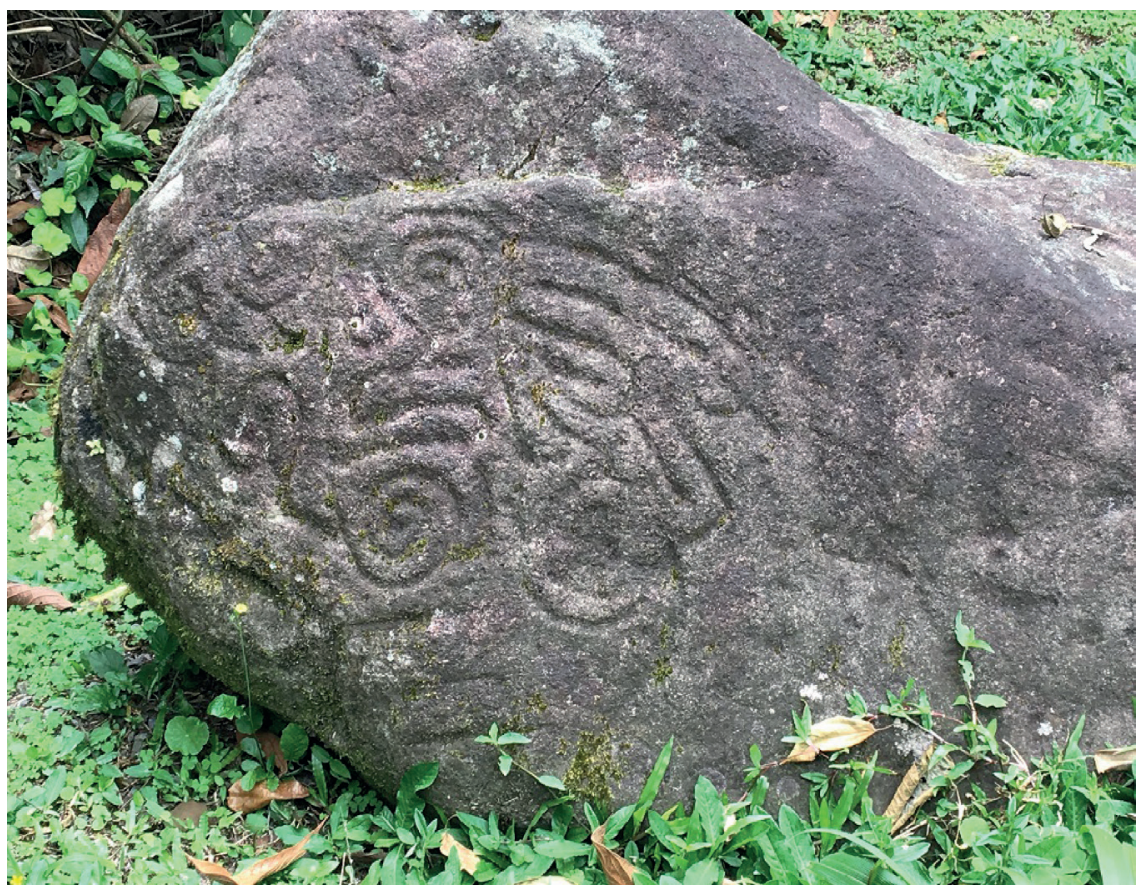

Fuente: fotografía de Susan Campos (2019).

Ilustración 1. Extensión del panorama urbano. Supremacía del gris

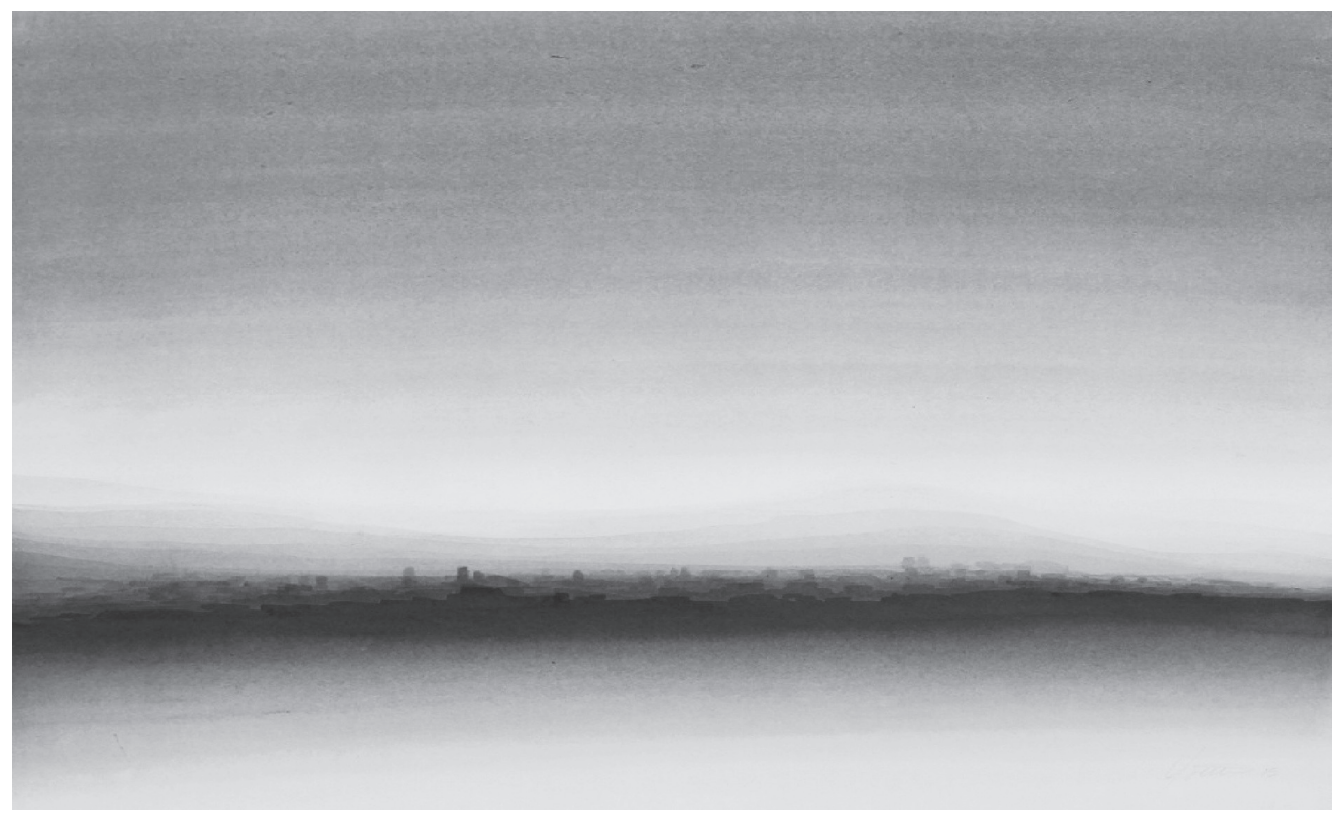

Fuente: Jose Pablo Ureña (2015). Acuarela sobre papel, 50x70cm. 


\section{Ilustración 2. Síntesis del diseño de un petroglifo de Ta‘lari}

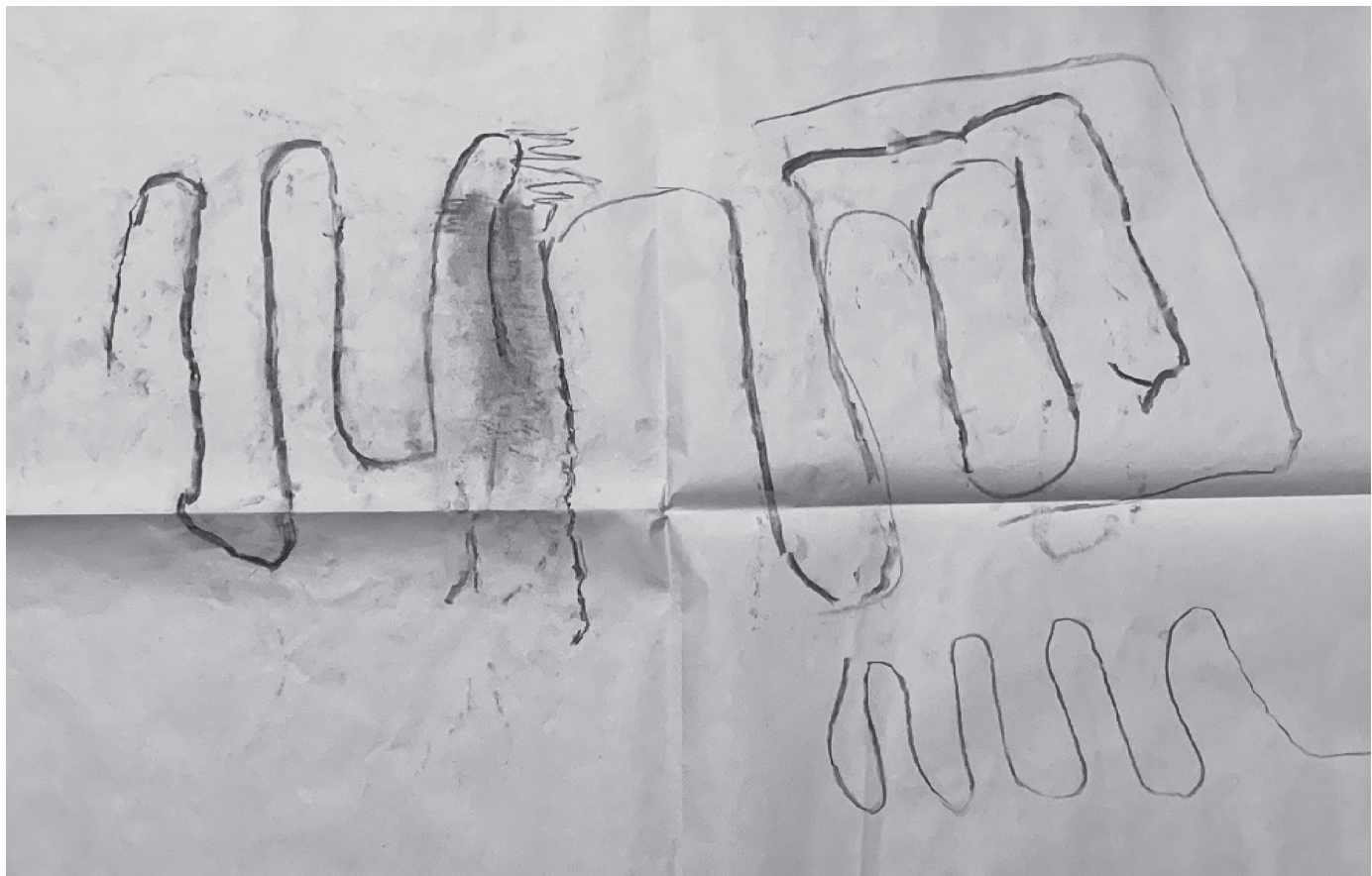

Fuente: Susan Campos (2019). Dibujo (huella del petroglifo en papel).

\section{Ilustración 3. Ejemplo de un clúster}

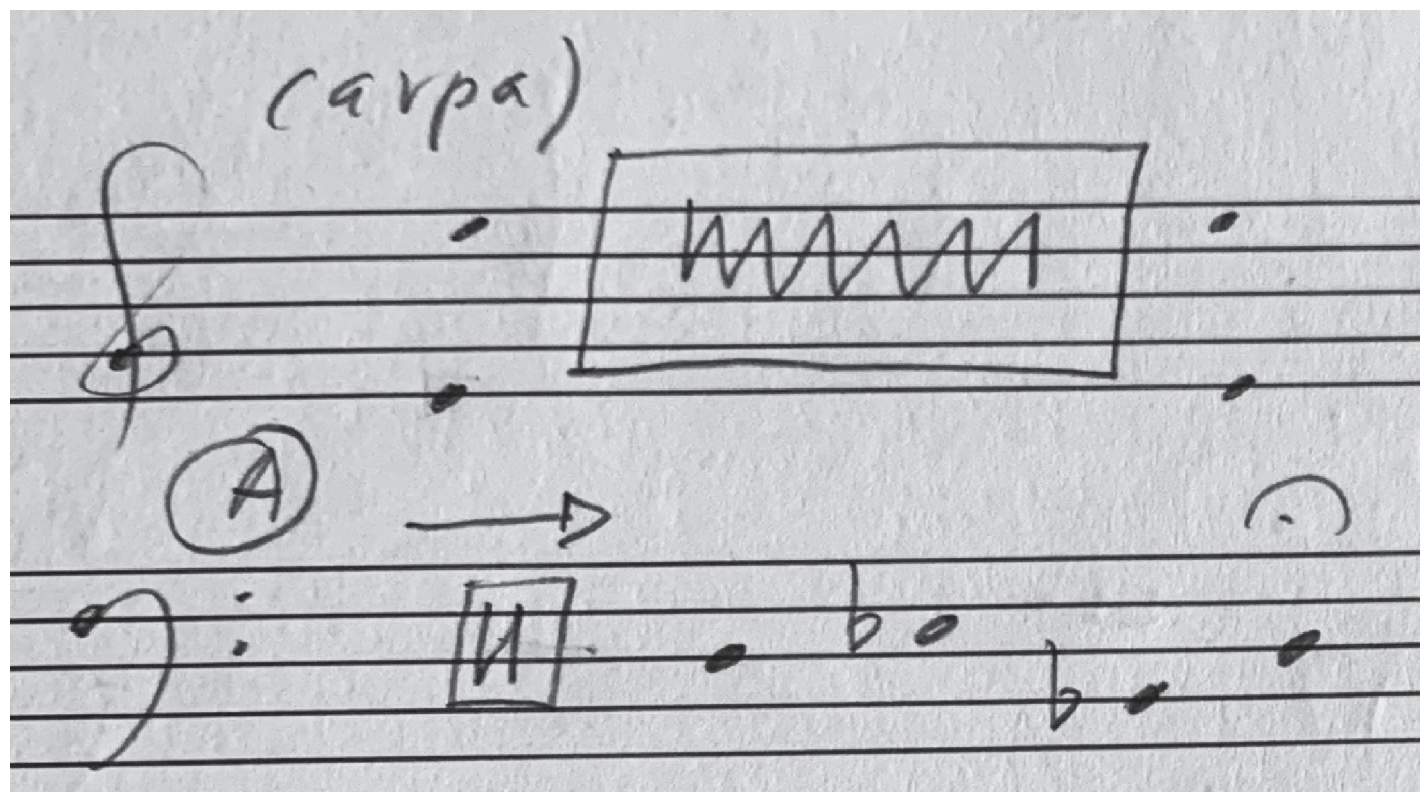

Fuente: partitura de Susan Campos (2017). 